\title{
Smart by Oneself? An Analysis of Russian Regional Innovation Strategies within the RIS3 Framework
}

\author{
Evgeniy Kutsenko \\ Head of Cluster Policy Unit, Centre for Industrial Policy, ekutsenko@hse.ru \\ Ekaterina Islankina \\ Research Fellow, Cluster Policy Unit, Centre for Industrial Policy, eislankina@hse.ru
}

Institute for Statistical Studies and Economics of Knowledge at the National Research University Higher School of Economics (HSE ISSEK), 11, Myasnitskaya str., Moscow 101000, Russian Federation

\author{
Alexey Kindras \\ Independent Expert, kindrasa@mail.ru
}

\begin{abstract}
$\mathrm{L}$ ess than a decade since its official introduction, smart specialization, which guides the selection of priorities for innovative development, has proven to be a farreaching academic idea and political instrument. In the European Union, smart specialization is mentioned among the ex ante conditions for receiving subsidies from European structural and investment funds. Its core principles are considered in innovation strategies in Australia, South Korea, and some countries of Latin America. In Russia, smart specialization is also being introduced in the agenda of policymakers.

The paper seeks to reveal which levels of governance should be involved in the design of a smart specialization

strategy and which factors should be the focus of attention when using this approach. The research is based upon an analysis of the innovation strategies of seven Russian regions, conducted with the adapted RIS3 Self-Assessment Wheel.

The results of the study empirically confirm that most principles of smart specialization are considered, at least formally, in the traditional innovation strategies of Russian regions. At the same time, without common rules for the selection, verification, and synchronization of innovative priorities as well as a single analytical database, organizational support, and expertise, even regions considered strong innovators fail to find their smart specialization.
\end{abstract}

Keywords: smart specialization; regional innovation strategy; regions; Smart Specialization Platform; interregional cooperation.

Article type: research paper
Citation: Kutsenko E., Islankina E., Kindras A. (2018) Smart by Oneself? An Analysis of Russian Regional Innovation Strategies within the RIS3 Framework. Foresight and STI Governance, vol. 12, no 1, pp. 25-45. DOI: 10.17323/25002597.2018.1.25.45 
$\mathrm{P}$ romoting innovation is a national policy priority and a part of the relevant agenda in many countries [European Commission, 2009, 2010; OECD, 2012a]. In recent years, regions commanded increasingly more attention in this context [EU CoR, 2016; Bellini, Landabaso, 2007; Charles et al., 2000]. Spatial proximity and local factors play an important role in knowledge creation and in transforming it into innovative products: OECD studies revealed extremely active interaction between innovative actors located within about a 200-kilometer radius from one another [OECD, 2013, p. 13]. However, innovation processes are distinctly region-specific. For example, regions' innovation activity depends upon the profoundly uneven distribution of R\&D potential. In particular, two-thirds of the total R\&D expenditures in the US are made by just 10 states [NSF, 2007]. Similarly, $58 \%$ of patent applications, $30 \%$ of R\&D expenditures, and $25 \%$ of highly skilled professionals are concentrated in $10 \%$ of the largest regions in OECD member countries [OECD, 2013a, p. 15]. Innovation activities are exceptionally varied, and R\&D leadership is by no means the only source of innovations. Innovations related to social processes, culture, and creative industries as well as the creation and development of new business models are no less important for regional development. The above stresses that each region has its own development path, while universal innovation promotion recipes do not always turn out to be adequate, not by far [Tödtling, Trippl, 2005].

Regions' growing interest in innovation was accompanied by the increased application of a systemic approach to its promotion in the R\&D sphere (the regional innovation systems concept [Asheim, Isaksen, 1997, 2002; Cooke, 1992, 2002]; learning regions [Florida, 1995; Morgan, 1997]; innovative environment [Camagni, 1995; Maillat, 1997]; innovation networks [Cooke, 1999; Doloreux, 2004]); and in the political domain (clusters [Porter, 1990, 1998], smart cities [Glaeser, Berry, 2006; Hollands, 2008], and civic universities [Goddard et al., 2013]). Having turned into a strategic planning area at the regional level [Landabaso et al., 1999; Charles et al., 2000; IRE, 2008], most regions in the innovative sphere did not eliminate their various flaws [Foray et al., 2009; Technopolis Group, 2011; Capello, Kroll, 2016]. Many regional innovation strategies remain removed from the global economic and technological contexts, in effect boiling down to a simple imitation of successful regions' behavior. The proposed measures are mostly aimed at supporting R\&D, not promoting demand or market access. Such documents are often focused on fashionable topics or prestigious projects (e.g., information and communication technologies (ICT), bio- or nanotechnology), even if the region lacks the sufficient number of companies specializing in such areas. On the other hand, traditional industries still have priority over more complex interindustry and inter-cluster projects.

The above problems are further aggravated by insufficient coordination between different-level agencies, leading to the duplication of support initiatives and the dispersal of limited resources, which ultimately undermines the efficiency of government regulation. At the political level, this issue was first articulated in the European Union (EU), which was concerned with finding a balance between the various decisionmaking levels. One would have thought that a logical way to eliminate the duplication of competences and fragmentation of support measures would be setting development priorities for each EU region. However, the complexity and diversity of modern technologies, and that of their economic applications [OECD, Eurostat, 2005; Smith, 2006; Warwick, 2013], make centralizing this sphere an extremely risky proposition. The European Commission funded the development of regional innovation strategies, first of all in unitary nations, i.e., the new member states with no decentralization experience or traditions [Morgan, Nauwelaers, 1999]. More than 100 such projects were supported since 1995, but the overall productivity of this effort has turned out to be insufficient due to the low quality of regional strategic governance. An alternative to the approaches that failed to live up to expectations became smart specialization strategies (S3).

Smart specialization is a collection of rules for setting priorities in the scope of an innovative development strategy. The rules are presented in a single EU methodological document titled "Guide to Research and Innovation Strategies for Smart Specialisations" [European Commission, 2012] (further, the Guide). Smart specialization implies a division of responsibilities between management levels: at the (supra) national level, the general conditions for strategy development and implementation are set, along with the verification of priorities and the creation of unified databases for analytical comparison; at the regional level, the actual priority setting for innovative development takes place, together with the development and implementation of strategies and the establishment of relevant coordination structures. On the Smart Specialization Platform website, ${ }^{1}$ more than 170 registered regions present their innovation priorities identified using the common European methodology [European Commission, 2016b].

Proposed by the Knowledge for Growth expert group of the European Commission's Directorate-General for Research and Innovation [Foray et al., 2009] only in 2009, the smart specialization concept found very strong demand in the economic policy domain. Its official definition is provided in the European Parliament's Directive of December 17, 2013; according to it, smart specialization strategies are:

\footnotetext{
${ }^{1}$ Access mode: http://s3platform.jrc.ec.europa.eu/, last accessed on 17.06.2017.
} 
... the national or regional innovation strategies which set priorities in order to build competitive advantage by developing and matching one's own research and innovation strengths to business needs in order to address emerging opportunities and market developments in a coherent manner, while avoiding the duplication and fragmentation of efforts [European Parliament, 2013].

Having such strategies in place is a precondition for regions' receiving subsidies from the European structural and investment funds (ESIF), whose combined budget for 2014-2020 amounts to 454 billion euros [European Commission, 2016a].

The smart specialization concept has also been adopted outside the EU, and is currently applied by the OECD [OECD, 2012b, 2013b] and the UN [UNECE, 2014, 2015]. Some of the relevant principles are reflected in Australian and South Korean innovative development strategies [OECD, 2013b]. In the scope of the Polos de Competitividad project, ${ }^{2}$ Argentina, Brazil, Colombia, Costa Rica, Mexico, Peru, Uruguay, Ecuador, and Chile created a databank comprising 579 industry-specific priorities for 49 regions using smart specialization tools [Guillonnet et al., 2015; del Castillo et al., 2016]. However, the active borrowing of relevant principles and methodologies by various countries puts into doubt the very possibility of designing smart innovation development strategies for specific regions without having an open (supra)national comparison system and standardized requirements to document quality, which so far only exist in the EU. This paper addresses this issue by using the example of seven Russian regions which have adopted their own innovative development strategies. Our objective is to find out which smart specialization characteristics can be considered "natural" ones, i.e., those inherent to high-quality regional strategies including those designed before the relevant methodological recommendations were published and which require special effort outside the scope of strategic regional governance.

\section{Literature Review}

The smart specialization concept was originally proposed in a series of studies conducted in 2007-2009 [Foray, van Ark, 2007; Foray et al., 2009], which have subsequently engendered more than a hundred publications $^{3}$. As the authors note,

The smart specialisation phenomenon is by no means new. $<\ldots>$ This simple idea was around for quite some while, and only needed some academic legitimacy [Foray et al., 2011, p. 4-6].

An analysis of papers on the subject allows one to identify the properties distinguishing "smart" strategies from conventional ones. First of all, the former take into account the regional economy's profile [Barca et al., 2012; McCann, Ortega-Argilés, 2016]. The application of tacit knowledge and local competences to set development priorities leads to differentiation and the creation of unique market niches for regional investments [Edmondson et al., 2014; OECD, 2013b; Frenken et al., 2007]. Another distinctive feature of smart specialization strategies is their substantiation using an extensive empirical basis [Kroll et al., 2014]: they contain verifiable performance indicators which meet the requirements of numerous expert evaluation studies [Barca, 2009]. The single-industry priority setting principle inherent in conventional strategies is being replaced by approaches based on diversification, related variety [Boschma, Iammarino, 2009; McCann, Ortega-Argilés, 2015], and strong interdisciplinary links [Foray, 2013; Kroll, 2015]. Smart specialization originates at the junction of industries and their intersection with new emerging S\&T areas where the region has a chance to become a leader. This multi-discipline approach provides an answer to global socioeconomic challenges, which require moving beyond the scope of the conventional knowledge areas' nomenclature [Foray et al., 2009]. The inter-industrial nature of smart specialization implies the need to set priorities which merge industrial, technological, and social competences in a new way, for example, this can be done by using ICT to lead an active, healthy lifestyle during one's later years [Iacobucci, Guzzini, 2016; Giannitsis, 2009].

An important objective of setting innovative development priorities is finding a unique niche for the region on the map of future markets and technologies [Foray et al., 2011; Hidalgo, Hausmann, 2009]. Foresight as a smart specialization tool [European Commission, 2012, p. 33] that helps identify global technology trends in the current and potential industries of regional specialization and offers a range of formats for joining various players' efforts and methods for improving communications between them.

Smart specialization studies are frequently based on a broad understanding of innovation as a strictly science-oriented process based on R\&D results or as user-initiated social and service innovations, which belong in the medium- and low-tech industries. This understanding can prompt structural changes in the regional economy [Hughes, 2012; Moretti, 2012; World Bank, 2010; Edmondson et al., 2014; Kroll, 2015]. One of the approaches to smart specialization implies matching the region's competences to generalpurpose technologies such as, for example, micro- and nano-electronics, photonics, nanotechnology, industrial biotechnology, new materials, advanced production technologies, and ICT [Larsen, 2011].

\footnotetext{
2 The project's objective was to find new approaches to economic transformation with an emphasis on innovation and increased cooperation with the EU. The project is sponsored by the EU-LAC foundation established in 2010 by heads of the EU countries and members of the Community of Latin American and Caribbean States. The foundation strives to strengthen cooperation between countries located on both sides of the Atlantic, promote joint projects, and extend the value chains. On October 25, 2016, the foundation received international organization status.

3 According to Scopus, as of 24.01.2017.
} 
Box 1. The Guggenheim Effect

Apart from the regions that develop or scale generalpurpose technologies, there are territories where innovative development is driven not by engineering knowledge per se, but by its amalgamation with the humanities. For example, developing specialized software for finding historical artifacts helped Florence become a major global center of advanced information technologies for archaeological applications. This result would hardly have been possible had the stake been made on developing the ICT industry as a whole. Such a cumulative effect from specific innovations in arts and architecture was named after the branch of the Solomon Guggenheim Museum of Modern Art, which has turned the provincial industrial town of Bilbao into a fashionable tourist center. This effect has transformed depressionstruck areas into prosperous global centers through the creation of unusual art objects and is capable of powerfully affecting the local economy. Located in northern Spain, Bilbao was able to successfully deal with the 1970s-1980s recession by implementing its Strategic Reconstruction Plan, the core element of which was building a worldclass art gallery.

Source: [Vicario, Monje, 2003].

Very few regions have the groundwork R\&D results in the above areas. Others should concentrate on applying the available results and products in priority activity areas to increase their efficiency.

Smart specialization researchers stress that developing a high-quality strategy begins with finding the region's place in global value chains, followed by analyzing and benchmarking other similarly structured territories [Thissen et al., 2013; Kroll, 2015]. Strategies should be open and must be subjected to external evaluation by "critical friends" - experts from other regions with a similar specialization [European Commission, 2012] The potential for inter-regional cooperation must be assessed over the course of the strategy's development taking into account the natural interconnection of various regions' smart specializations [Foray, 2013; Iacobucci, 2014]. Making use of the various formats for inter-regional cooperation is believed to be an important aspect of (supra)national strategic planning, particularly for the allocation of resources and the coordination of innovation promotion initiatives [Iacobucci, Guzzini, 2016].

Synchronization, i.e., multiphase management based on smooth communications and a clear division of responsibilities between various levels, is seen as another feature of smart specialization strategies [McCann, Ortega-Argilés, 2016; Kroll et al., 2014; Barca, 2009]. At the regional level, all stakeholders become involved in priority-setting, strategy development, and implementation. On the (supra) national level, more basic strategizing rules are formulated, along with the requirements for innovative development priorities and their verification. Unified databases for an analytical comparison are also created. Finally, synchronization implies finding a balance between the bottom-up (entrepreneurial search) and top-down (bureaucratic priority setting and strategy development) approaches [McCann, Ortega-Argilés, 2014].

Entrepreneurial search - one of the central ideas of the smart specialization concept - frequently leads to the emergence of practical problems [Estensoro, Larrea, 2016]. The chances that entrepreneurs will be able to identify promising areas for the region's leadership on their own are quite small [Iacobucci, 2014]. The linear growth of specialization areas seems to be a more realistic scenario than efficient priority setting by a wide circle of players [Boschma, 2014]. Interaction with the regional community may turn out to be less than efficient if small groups pursuing their own vested interests usurp communications with the public authorities. A possible remedy for that is multilevel coordination [Coffano, Foray, 2014; Capello, 2014; Kroll, 2015; Estensoro, Larrea, 2016].

Table 1 summarizes the main characteristics of smart specialization strategies presented in the literature and shows under which conditions and at which management level regional innovation strategies would match these criteria.

Trying to select one key characteristic out of the aforementioned ones leads one to conclude that when applied to regional strategies, the adjective "smart" actually means "unique". However, it is not support measures that are unique (it would be impossible to design specific tools for each particular region), but the development priorities, which channel competences and resources accumulated in the region over the course of entrepreneurial search into new areas of activity [Hausmann, Roderik, 2003].

Each area's uniqueness is due to an increased regional division of labor. Without being valuable in itself, this brings benefits even in the absence of an adequate cost difference [Ricardo, 1817; Formaini, 2004]. Another source of uniqueness is differentiation used as a competitive tool (along with price leadership). The latter threatens long-term prosperity and is unavailable in "expensive" (in terms of production costs) countries, including the EU members. Such nations must compete on the basis of business conditions, human capital, and by making their positions unique among other territories. In this case "unique" means "no cheaper alternatives are available". If regions belong in the same country or union, uniqueness prompts one to look for solutions beneficial to all concerned parties (a win-win strategy). Increased 
Table 1. Characteristics of Smart Specialisation Strategies

\begin{tabular}{|c|c|c|}
\hline Characteristic & Implementation conditions & Level \\
\hline Making use of the region's unique competitive advantages & \multirow{5}{*}{$\begin{array}{l}\text { Following recommendations in the Guide to } \\
\text { Research and Innovation Strategies for Smart } \\
\text { Specialisations [European Commission, 2012] }\end{array}$} & \multirow[t]{5}{*}{ Regional (internal) } \\
\hline Selecting valid specialization areas & & \\
\hline Setting inter-industrial priorities & & \\
\hline A broad understanding of innovation & & \\
\hline Orienting oneself towards future markets and technologies & & \\
\hline $\begin{array}{l}\text { Taking into account other regions' strengths and } \\
\text { specialization areas, including foreign ones }\end{array}$ & \multirow{2}{*}{$\begin{array}{l}\text { Having a top-level structure that sets } \\
\text { requirements for the strategies, and ensures their } \\
\text { compatibility (an analogue of the EU Smart } \\
\text { Specialisation Platform) }\end{array}$} & \multirow[t]{2}{*}{$\begin{array}{l}\text { (Supra)national } \\
\text { (external) }\end{array}$} \\
\hline Synchronizing with different management levels & & \\
\hline
\end{tabular}

diversity also increases the probability of designing new, successful regional development models and the increased efficiency of public R\&D investments.

Here uniqueness is achieved by combining internal knowledge (which is personalized, unavailable outside the region, and obtained over the course of the entrepreneurial search) with external knowledge (global trends, other regions' strategies, and (supra)national priorities and programmes). It would not be possible to find a unique development path on the basis of internal knowledge alone because uniqueness is a relative category which becomes meaningful only by comparison. Unlike the conventional approach which implies an analysis and replication of more successful regions' best practices, learning from other

\section{Box 2. Setting up Regional Specialization Areas in the Context of the EU Priorities and Target Markets}

Many of the regions registered on the Platform have chosen agriculture and the food industry as their priority competency areas (the left figure). However, if we overlay the EU's health and safety priorities, the number of competitive regions drops (the figure at the center). Finally, if we project the selected specialization areas over the target health-related markets, just one region retains a competitive advantage (the right figure). Thus, Spanish Galicia found its unique niche in the healthy foods segment. Food industry innovations as a basis of healthy lifestyles and longevity became one of the three priorities of the region's smart specialization strategy for 20142020. The region had all the necessary prerequisites: an aging population ( $23 \%$ of the residents were aged $65+$ ) and one of the highest shares of the food industry in the GRP in Southern Europe. Interestingly, for a long time this industry remained quite conservative in terms of the technologies it used. The strategy designers noted this fact and improved upon the conventional approaches by applying innovative solutions.

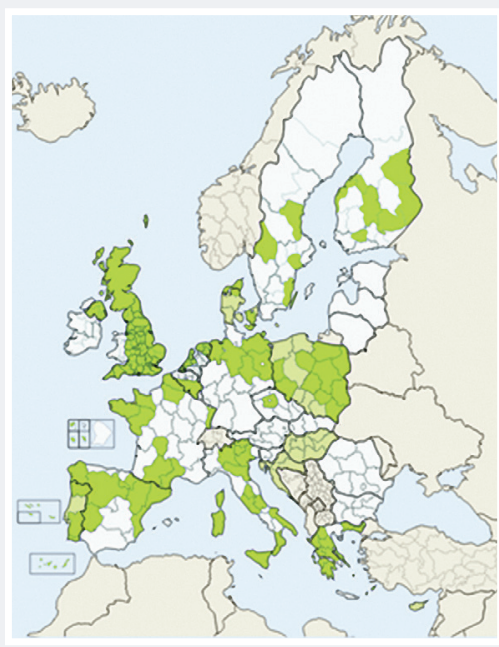

(1) Regional competences: agriculture, food industry

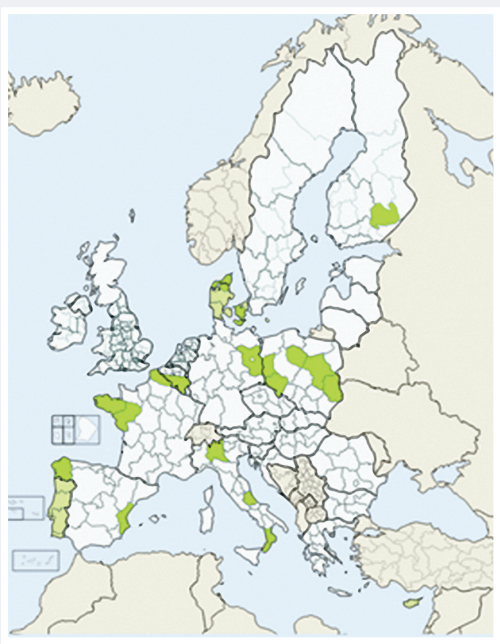

(1)+(2) EU priorities: people's health and safety

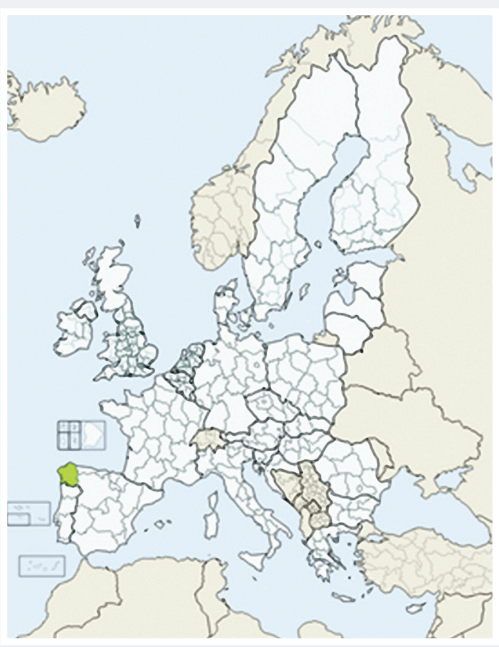

$(1)+(2)+(3)$ EU target markets: healthcare

Source: composed by the authors [Xunta de Galicia, 2014; European Commission, 2016b]. 
regions in the smart specialization perspective is aimed at finding, and substantiating, one's own, original solutions.

The internal component of smart specialization can by now be deemed thoroughly developed. The Guide describes six strategy development steps: analyzing the regional context, setting up management structures, forging a common vision, setting priorities, implementing policies, and monitoring and evaluating. Additional information is readily available as well - the proceedings of international conferences $^{4}$ and specialized reports [Ketels et al., 2013; Foray, Goenaga, 2013; Gianelle, Kleibrink, 2015]. Therefore, implementing a smart specialization strategy only requires a relevant decision by the regional authorities, since the "entry threshold" for regions outside the EU is relatively low. It is therefore hardly surprising that some non-EU regions have already started designing their own innovation strategies following the smart specialization model [OECD, 2013b; del Castillo et al., 2016].

To provide external knowledge to the EU regions, a specialized open Smart Specialization Platform (S3 Platform, further on referred to as the Platform) was established in 2011 on the basis of the European Commission Joint Research Centre (JRC). Unlike the Guide, the Platform's practical experience as an applied institutional innovation is poorly reflected in the literature [McCann, Ortega-Argilés, 2016; Capello, Kroll, 2016]. It is designed to provide information, methodological, and expert support for the national and regional authorities and to promote mutual learning and inter-regional cooperation [European Commission, 2016b]. The Platform's research and project team comprises 21 people, and its Coordination Council includes representatives from six General Directorates of the European Commission ${ }^{5}$. A database of priorities was created in the framework of the Platform, currently featuring more than a thousand entries. The priorities are broken down into several categories, allowing regions to present their specialization in considerable detail. The Platform uses various analytical and organizational tools which help to make use of regions' unique competitive advantages when designing their development strategies.

The costs associated with transplanting the external smart specialization component into countries outside the EU would be relatively high, since this requires their national authorities to make relevant decisions and allocate sufficient resources. This probably explains why so far attempts to apply smart specialization strategies were primarily made at the regional level: it is the regions who take targeted steps to improve the strategy's quality by adapting specific principles described in the Guide. There is no information about any attempts to create something like the Platform to deal with the lack of external knowledge at the national or supranational level.

It is commonly believed that the lack of global perspective significantly reduces the quality of the strategy: it would be very difficult (if at all possible) for regions to overcome innovation-related bottlenecks on their own, even if they followed the right recommendations [Kroll, 2015; Capello, Kroll, 2016]. An authority responsible for setting requirements for strategies and for their valid compatibility is needed to take necessary corrective action. [Landabaso, 2014; McCann, Ortega-Argilés, 2014]. Fragmented data about specific strategies' flaws [Reid, Stanovnik, 2013; Iacobucci, 2014; Capello, Kroll, 2016] are insufficient to definitively establish which factors, internal or external, create the biggest problems. In particular, this is due to the fact that existing studies are mostly devoted to EU countries where the Platform is in place, which allows them to reduce the shortage of external knowledge. The experience of countries lacking such tools clearly demonstrates the true value of the Platform.

Our objective is to acquire a deeper understanding of the scope for and suitability of applying the smart specialization concept to countries outside the EU. This implies assessing the productivity of its application at the regional level, the sufficiency of locally made decisions and locally available resources, or, on the contrary, the need for an upper-level regulatory authority. In the latter case, decisions made even by the most advanced regions should be deemed insufficient by default; a systemic national-level approach would be preferable (political will, resources, time). In our opinion, the number of countries applying various elements of the smart specialization concept will only keep growing, so it is important to find out exactly which of its characteristics seem clear and logical to the regional authorities, and which should be studied and explained in more detail.

Two hypotheses on how regional innovation strategies adopted by countries outside the EU match the smart specialization criteria are proposed, using Russian regions as examples:

Hypothesis 1: Regional innovation strategies (including those developed before the publication of the Guide in 2012) do have most of the smart specialization characteristics, at least formally.

Hypothesis 2: Without national-level coordination (standardized rules for setting, verifying, and synchronizing priorities, a common analytical database, organizational support), even the most advanced innovative regions will not be able to develop a smart strategy on their own.

The object of our study is strategies, not regions. While we are aware of the mismatch between the actual state of affairs and official documents, we still believe that on the whole, the latter do provide

\footnotetext{
${ }^{4}$ E.g.: $1^{\text {st }}$ SMARTER Conference on Smart Specialisation and Territorial Development, September 28-30, 2016, Seville, Spain. See http://www.regionalstudies.org/conferences/conference/smart-specialisation for more (last accessed on 23.03.2017).

${ }^{5}$ Directorates for Region and Urban Policy; Research and Innovation; Education and Culture; Agriculture and Rural Development; Internal Market, Industry, Entrepreneurship and SMEs; Communications Networks, Content and Technology.
} 
reliable indicators of the quality of regional-level strategic management. We also accept that regions may objectively opt for a specialization that might not necessarily match the officially established priorities. At the same time, the current specialization should not be confused with priorities reflecting a vision of the future. Regions seem to be in the best position to forge the latter, since they merge local and global knowledge and, given efficient communication, such priorities do serve as a basis for strategies.

Though originally formulated and institutionalized in the EU, smart specialization rules still are not Europe-specific and can be applied elsewhere. Firstly, they are largely based on best practices accumulated the world over. Secondly, they are particularly relevant in countries which face similar problems with managing regional development, such as uncoordinated support initiatives and the duplication of priorities, which in turn is due to a large territory, significant regional diversity, and the high level of autonomy of national provinces (regions) or union members. The above problems are also present in Russia, albeit not exactly to the same degree as those in the EU, so many of the smart specialization characteristics, even given the lack of standardized federal-level requirements, are in fact reflected in Russian regions' innovative development strategies.

\section{Initial Data and Methodology}

The Russian case study is perfect for testing our hypotheses given the relative comparability with the EU in terms of size, geographical diversity, and the relevance of the challenges of duplication and innovation policy fragmentation. The country is among the ten largest in the world in terms of population and GDP at purchasing power parity [Eurostat, 2016; U.S. Census Bureau, 2016; Rosstat, 2016; International Monetary Fund, 2016].

In addition to geographical, environmental, climatic, demographic, and socio-cultural diversity, Russia also demonstrates significant disparity in the regions' socioeconomic development, an uneven distribution of economic potential, and residential patterns.

Differentiation between the most and least developed regions' monthly per capita monetary income deciles is 3.3 times; note that in just $25 \%$ of them is this indicator higher than the Russian average value [Rosstat, 2016].

The federal system implies that regional administrations pursue their own policies within their spheres of competence $^{6}$, including innovation policy. In 2014, about half of the regions implemented such policies to a varying degree (Figure 1). For example, 42 regions designed strategic innovation activity plans and 35 had in place long-term socioeconomic strategies ${ }^{7}$ which paid significant attention to promoting innovation-based development. Seven regions adopted specific innovation strategies, including the Ingush Republic (innovation strategy approved in 2012) ${ }^{8}$, Tatarstan $(2008)^{9}$, the Kamchatka (2010) ${ }^{10}$, Krasnoyarsk (2011) $)^{11}$, Stavropol (2009) $)^{12}$, Sverdlovsk (2013) ${ }^{13}$, and Chelyabinsk (2012) $)^{14}$ Regions.

The following hypotheses were tested:

Hypothesis 1: Russian regions' innovation development strategies on the whole do reflect each of the six steps of the smart specialization methodology but only meet a third of the relevant criteria. The steps specifically addressing development and implementation issues (priorities, policies, monitoring and evaluation) match a larger number of criteria than the steps taken at the preparatory stage (analyzing regional context, management, common vision).

Hypothesis 2: Innovation development priorities specified in the strategies are poorly justified; they frequently do not take into account the region's potential and opportunities, and/or the competitive advantages of other territories. In most cases, productivity indicators do not allow one to measure growth in the selected specialization areas. The various formats used to set priorities and performance indicators

\footnotetext{
${ }^{6}$ Constitution of the Russian Federation, 1993, art. 73. Access mode: http://www.constitution.ru, last accessed on 22.02.2017.

${ }^{7}$ Federal Law “On Strategic Planning in the Russian Federation” No. 172-FZ of 28.06.2014.

${ }^{8}$ Innovation Development Strategy of the Ingush Republic until 2025. Approved by the Government of the Ingush Republic's Order No. 433-r of 30.06.2012. Access mode: http://www.ingushetia.ru/m-news/archives/Komitet.doc, last accessed on 21.01.2018.

9 Strategy for Development of Innovation and Research Activities in the Republic of Tatarstan until 2015. Approved by the Tatarstan Republic's Presidential Decree No. UP-293 of 17.06.2008. Access mode: http://docs.cntd.ru/document/917029427, last accessed on 21.01.2018.

${ }^{10}$ Innovation Development Strategy of the Kamchatka Region until 2025. Approved by the Kamchatka Regional Government's Order No. 594-RP of 03.12.2010. Access mode: http://docs.cntd.ru/document/446224061, last accessed on 21.01.2018.

${ }^{11}$ Innovation Development Strategy of the Stavropol Region until 2020. Approved by the order of the Stavropol Regional Ministry of Economic Development No. 220/od of 29.06.2009. Access mode: http://docs.cntd.ru/document/424060824, last accessed on 21.01.2018.

${ }^{12}$ Innovation Development Strategy of the Krasnoyarsk Region until 2020 "Innovation Region 2020". Approved by the Governor of the Krasnoyarsk Region's Decree No. 218-UG of 24.11.2011. Access mode: http://docs.cntd.ru/document/985024710, last accessed on 21.01.2018.

${ }^{13}$ Innovation Development Strategy of the Sverdlovsk Region until 2020. Approved by the Sverdlovsk Regional Government Order No. 646-PP of 22.05.2013. Access mode: http://docs.cntd.ru/document/453135952, last accessed on 21.01.2018.

${ }^{14}$ Innovation Development Strategy of the Chelyabinsk Region until 2020. Approved by the Chelyabinsk Regional Government Regulation No. 260-rp of 12.10.2012. Access mode: http://docs.cntd.ru/document/444933641, last accessed on 21.01.2018.
} 
Figure 1. Quality Indicators of Russian Regional Innovation Policies: 2014

\section{Quality parameters}

The presence of a regional innovation development strategy, or a relevant division for promoting innovation within the overall regional development strategy

The regional territorial development scheme specifies a priority innovation development zone

The presence of a specialized regional legislation that specifically establishes basic principles of innovative activities in the region

The presence of a specific regional innovation promotional programme

The presence of special innovation policy bodies to consult the head of the regional government

The presence of regional development institutes responsible for promoting innovation activities
Number of regions

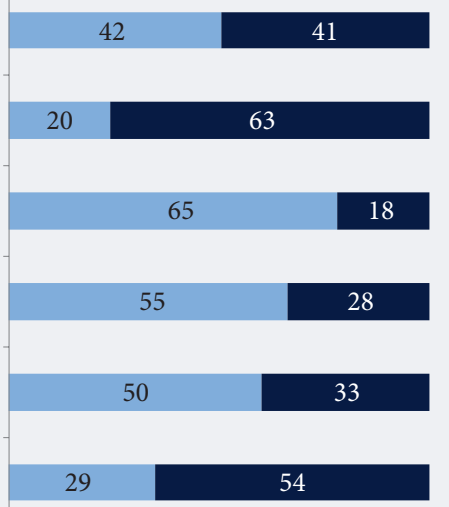

Note: At the time of the study no data was available for Crimea and Sebastopol.

Source: composed by the authors, based on [HSE, 2016].

reduce the opportunity for comparing the documents and hinder the creation of unique regional strategies.

"Pure" conditions for testing the above hypotheses include absence of the following:

- the "smart specialization" phrase in the 2012-2013 strategies (i.e., those approved after the Guide was published);

- specific indications that this concept was considered and taken into account;

- relevant directives by the federal authorities;

- analogues of the Smart Specialization Platform in Russia.

The paper presents an analysis of seven Russian regional innovative development strategies to assess how they match the smart specialization criteria. Socioeconomic development strategies only containing specific sections on promoting innovation and innovation development concepts were not analyzed, because they do not fully match the definition of a smart specialization strategy. The study was based on open information sources including the regional administrations' official websites and specialized legislation databases.

The regions which adopted innovation development strategies are quite different, both in terms of their macroeconomic indicators (Figure 2), and innovative development level (Table 2).

The regions under study include the leader of the national ranking (the Republic of Tatarstan, $1^{\text {st }}$ place) and outliers (the Kamchatka Region at the $71^{\text {st }}$ position and the Ingush Republic at $82^{\text {nd }}$ ). The Krasnoyarsk, Stavropol, Sverdlovsk, and Chelyabinsk Regions are among the top 25 in terms of overall regional innovative potential. The analysis of the sample did not reveal any patterns: specialized strategies were developed in regions with quite different levels of and structures for innovation development.

The first hypothesis was tested using the adapted RIS3 Self-Assessment Wheel tool [European Commission, 2016b]. Basically, the methodology amounts to assessing regional strategies on a scale from 0 to 5 using 18 criteria which break down the six steps of designing smart specialization strategies described in the Guide. Accordingly, the Russian regions' strategies were also checked for matching the smart specialization criteria. The six-point scale was modified to a three-point one (from 0 to 1 ), where $0=$ no match, 0.5 = inferred match, and $1=$ clear match (see Table 3 ).

The second hypothesis was tested by checking the validity of specialization industries' selection and that of the performance targets specified in the analyzed documents.

\section{Results}

\section{Testing Hypothesis 1}

Table 4 and Figure 3 below present the summarized results of the analysis of the regional innovation strategies (detailed results, including the assessment of all documents, are presented in Table 5). The value " 7 " in the "Total score" column means that all seven documents clearly matched the relevant smart specialization criteria; zero indicates no match at all. A fractional number (e.g., 4.5) means that for at least one strategy a match was inferred. 


\section{Figure 2. Position of Regions that Have Innovation Development Strategies} in the Russian Regions' per Capita GRP Ranking (2014)

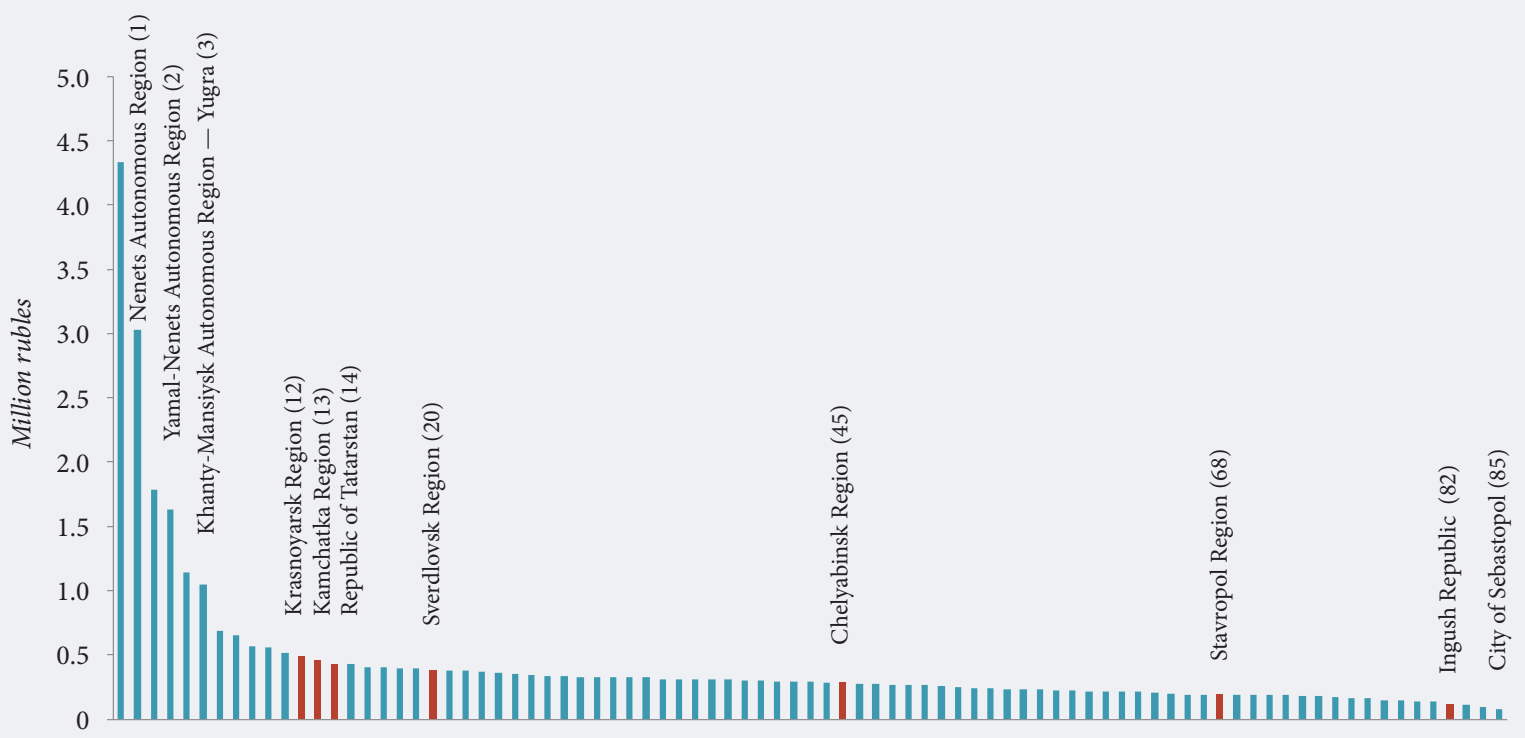

Note: regions that have innovative development strategies are highlighted in dark-red.

Source: [Rosstat, 2016].

The calculations show that Russian regional innovation strategies on average match $37 \%$ of smart specialization criteria. First of all, it applies to Steps 4 (priorities), 5 (policies), and 6 (monitoring and evaluation), which specify practical approaches to strategy development. As to the preparatory steps, i.e., Steps 1 (analyzing the regional context), 2 (management), and 3 (common vision), all strategies matched the relevant criteria only to a minimal degree (Figure 4)

The weakest aspects of the innovation strategies turned out to be "Analyzing the external environment" (Step 1) and "Involving a wide range of stakeholders" (Step 2). Practically all strategies saw innovations exclusively in R\&D terms and ignored global challenges (Step 3). Comparing the regions by their Russian Regional Innovation Index (RRII) values and by the degree of their innovation strategies' matching smart specialization criteria did not reveal any direct correlation between regional innovative potential and strategy quality. The Sverdlovsk Region, the leader in terms of matching the smart specialization criteria (11 out of 18) [HSE, 2016], has a relatively high position in the ranking (the $13^{\text {th }}$ ). However, the Krasnodar Region (12 $2^{\text {th }}$ place on the RRII) matches the smart specialization criteria only minimally (4 out of 18), while the Kamchatka Region ( $72^{\text {nd }}$ place on the RRII) comes second after the Sverdlovsk Region in criteria matching terms (matches 9 criteria out of 18). The Republic of Tatarstan's strategy ( $1^{\text {st }}$ place on the RRII) matches only one-third of the criteria (6 out of 18) (Figure 5).

To verify this conclusion, we compared the evaluation results for two regions with polar opposite positions on the innovative development ranking: the Republic of Tatarstan ( $1^{\text {st }}$ place) and the Ingush Republic (82 $2^{\text {nd }}$ place).

Table 2. Distribution of Regions by Russian Regional Innovation Index and Sub-indices (2014 data)

\begin{tabular}{|c|c|c|c|c|c|}
\hline \multirow[b]{2}{*}{ Region } & \multicolumn{5}{|c|}{ Ranking } \\
\hline & $\begin{array}{l}\text { Russian Regional } \\
\text { Innovation Index }\end{array}$ & \begin{tabular}{|c|} 
Socioeconomic \\
Conditions for Innovation \\
Activities Index \\
\end{tabular} & $\begin{array}{l}\text { S\&T Potential } \\
\text { Index }\end{array}$ & $\begin{array}{c}\text { Organizations' } \\
\text { Innovation Activities } \\
\text { Index } \\
\end{array}$ & $\begin{array}{l}\text { Regional Innovation } \\
\text { Policy Quality Index }\end{array}$ \\
\hline Republic of Tatarstan & 1 & 3 & 17 & 2 & 1 \\
\hline Krasnoyarsk Region & 12 & 19 & 19 & 22 & 6 \\
\hline Sverdlovsk Region & 13 & 14 & 13 & 14 & 26 \\
\hline Chelyabinsk Region & 18 & 12 & 28 & 21 & 29 \\
\hline Stavropol Region & 23 & 24 & 51 & 39 & 10 \\
\hline Kamchatka Region & 71 & 77 & 77 & 66 & 49 \\
\hline Ingush Republic & 82 & 81 & 83 & 82 & 60 \\
\hline
\end{tabular}


Table 3. Assessment Criteria for Russian Regions' Innovation Strategies

\begin{tabular}{|c|c|c|}
\hline No. & Criterion & Description \\
\hline \multicolumn{3}{|r|}{ Step 1. Analysing regional context } \\
\hline 1. & $\begin{array}{l}\text { Analyzing regional } \\
\text { resources }\end{array}$ & $\begin{array}{l}\text { - Analyzing strengths and weaknesses, threats and opportunities for creating innovations in the } \\
\text { region } \\
\text { - Describing innovative potential in the region's specialization areas } \\
\text { - Identifying unique competitive advantages of the regional innovation system's participants }\end{array}$ \\
\hline 2. & $\begin{array}{l}\text { Analyzing external } \\
\text { environment }\end{array}$ & $\begin{array}{l}\text { - Comparing the region with other regions } \\
\text { - Analyzing the experience of other regions with similar specialization areas (benchmarking) } \\
\text { - Analyzing inter-regional cooperation: trade, economic, S\&T, etc. }\end{array}$ \\
\hline 3. & $\begin{array}{l}\text { Analyzing } \\
\text { entrepreneurial activity }\end{array}$ & $\begin{array}{l}\text { - Assessing the level of the entrepreneurial environment in the region } \\
\text { - Presence of clusters, associations and alliances (business and consumer ones), start-up firms, } \\
\text { various forms of self-employment, live laboratories } \\
\text { - Identifying promising market niches }\end{array}$ \\
\hline
\end{tabular}

\section{Step 2. Management}

\begin{tabular}{|c|l|c|c|c|}
\hline 4. & $\begin{array}{l}\text { Putting in place a } \\
\text { multilevel management } \\
\text { system }\end{array}$ & $\begin{array}{l}\text { - Establishing specialized agencies responsible for strategy development (e.g., a supervisory board, } \\
\text { a project office, special working groups) } \\
\text { - Allocating duties and responsibilities (general management, current management, designing } \\
\text { specific projects) }\end{array}$ \\
\hline 5. & $\begin{array}{l}\text { Involving a wide range of } \\
\text { stakeholders }\end{array}$ & $\begin{array}{l}\text { - Involving various groups in strategy development: public authorities, businesses, R\&D } \\
\text { organizations, civil society, expert community (including experts from other countries/regions) }\end{array}$ \\
\hline 6. & $\begin{array}{l}\text { Developing management } \\
\text { and communication } \\
\text { techniques }\end{array}$ & $\begin{array}{l}\text { - Use of open, interactive formats for interaction between public authorities, businesses, and } \\
\text { citizens over the course of strategy development }\end{array}$ \\
\hline
\end{tabular}

\section{Step 3. Common vision}

\begin{tabular}{|c|l|l|l}
\hline 7. & $\begin{array}{l}\text { Using a broad } \\
\text { understanding of } \\
\text { innovation }\end{array}$ & $\begin{array}{l}\text { - Developing strategies keeping in mind the various forms of innovations including organisational, } \\
\text { social, service, and user-induced ones, as opposed to those only based on S\&T results }\end{array}$ \\
\hline 8. & $\begin{array}{l}\text { Addressing global } \\
\text { challenges }\end{array}$ & $\begin{array}{l}\text { - Setting innovation development priorities (initiatives, projects) on the basis of their contribution } \\
\text { to meeting global economic and social challenges }\end{array}$ \\
\hline 9. & Using scenario analysis & $\begin{array}{l}\text { - Preparing several innovation development scenarios for the region } \\
\text { - Preparing action plans for each possible scenario }\end{array}$ \\
\hline
\end{tabular}

\section{Step 4. Priorities}

\begin{tabular}{|l|l|l|}
\hline 10. & Setting priorities & \\
\hline 11. & Coordinating priorities & \\
\hline 12. & Achieving critical mass & \\
\hline
\end{tabular}

- Identifying a limited number of specific specialisation areas for the region (existing or potential), to promote the development of innovation and create/strengthen unique competitive advantages

- Taking into account the results of analysing the regional context and external environment, and the consolidated position of the regional innovation system's participants

- Coordinating one's priorities with national S\&T and innovation priorities

- Linking the selected priorities to general-purpose technologies

- Allocating adequate resources to implement selected priorities, and making sure the region has sufficient entrepreneurial potential to concentrate resources on the selected priorities

\section{Step 5. Policies}

\begin{tabular}{|c|l|}
\hline 13. & Using roadmaps \\
\hline 14. & $\begin{array}{l}\text { Implementing a balanced } \\
\text { set of measures }\end{array}$ \\
\hline 15. & $\begin{array}{l}\text { Creating adequate } \\
\text { framework conditions }\end{array}$ \\
\hline
\end{tabular}

- Making sure the strategy includes implementation plans (roadmaps) and pilot projects in the selected specialization areas

- Combining horizontal and precision support initiatives to implement the strategy

- Designing and implementing policies to improve the business climate, promote $\mathrm{R} \& \mathrm{D}$, civil initiatives, etc.

\section{Step 6. Monitoring and evaluation}

- Selecting a limited number of key performance indicators linked with specific priorities, objectives, and timeframes

- In place/absent

- In place/absent

\begin{tabular}{|c|l|}
\hline 16. & $\begin{array}{l}\text { Using performance } \\
\text { indicators }\end{array}$ \\
\hline 17. & $\begin{array}{l}\text { Strategy implementation } \\
\text { monitoring system }\end{array}$ \\
\hline 18. & $\begin{array}{l}\text { Mechanism for updating } \\
\text { the strategy }\end{array}$ \\
\hline
\end{tabular}

Note: Two criteria were modified: "Revision of the past priorities" was changed to "Setting priorities", and "RIS3 update" — to "Mechanism for updating the strategy".

Source: composed by the authors based on [European Commission, 2012]. 


\section{Table 4. Summarized Evaluation Results of Russian Regional Innovation Strategies}

\begin{tabular}{|c|c|c|c|}
\hline $\begin{array}{l}\text { Strategy development } \\
\text { step }\end{array}$ & Evaluation criteria & Total score & $\begin{array}{l}\text { Total for the } \\
\text { step }\end{array}$ \\
\hline \multirow{3}{*}{$\begin{array}{l}\text { 1. Analysing regional } \\
\text { context }\end{array}$} & Analyzing regional resources & 5 & \multirow{3}{*}{9} \\
\hline & Analyzing external environment & 1 & \\
\hline & Analyzing entrepreneurial activity & 3 & \\
\hline \multirow{3}{*}{ 2. Management } & Putting into place a multilevel management system & 3.5 & \multirow{3}{*}{9.5} \\
\hline & Involving a wide range of stakeholders & 2 & \\
\hline & Developing management and communication techniques & 4 & \\
\hline \multirow{3}{*}{ 3. Common vision } & Using a broad understanding of innovation & 0.5 & \multirow{3}{*}{6.5} \\
\hline & Addressing global challenges & 1.5 & \\
\hline & Using scenario analysis & 4.5 & \\
\hline \multirow{3}{*}{ 4. Priorities } & Setting priorities & 7 & \multirow{3}{*}{11.5} \\
\hline & Coordinating priorities & 2.5 & \\
\hline & Achieving critical mass & 2 & \\
\hline \multirow{3}{*}{ 5. Policies } & Using roadmaps & 0 & \multirow{3}{*}{11.5} \\
\hline & Implementing a balanced set of measures & 4.5 & \\
\hline & Creating adequate framework conditions & 7 & \\
\hline \multirow{3}{*}{$\begin{array}{l}\text { 6. Monitoring and } \\
\text { evaluation }\end{array}$} & Using performance indicators & 7 & \multirow{3}{*}{13.5} \\
\hline & Strategy implementation monitoring system & 5 & \\
\hline & Mechanism for updating the strategy & 1.5 & \\
\hline
\end{tabular}

The calculations (Figures 6 and 7) show that despite the almost threefold differentiation between these regions' innovative development level ${ }^{15}$, their strategies have quite similar characteristics:

- a poor preparatory stage (low scores for analysis, management, and common vision criteria), against the background of a quite advanced practical implementation stage (high scores for priorities, policies, and monitoring and evaluation criteria);

- a fragmented matching of smart specialization criteria: both strategies do reflect each of the six criteria specified in the Guide, but neither matches all the criteria.

\section{Figure 3. Summarised Results of Assessing Russian Regional Innovation Strategies' Matches with Smart Specialisation Criteria}

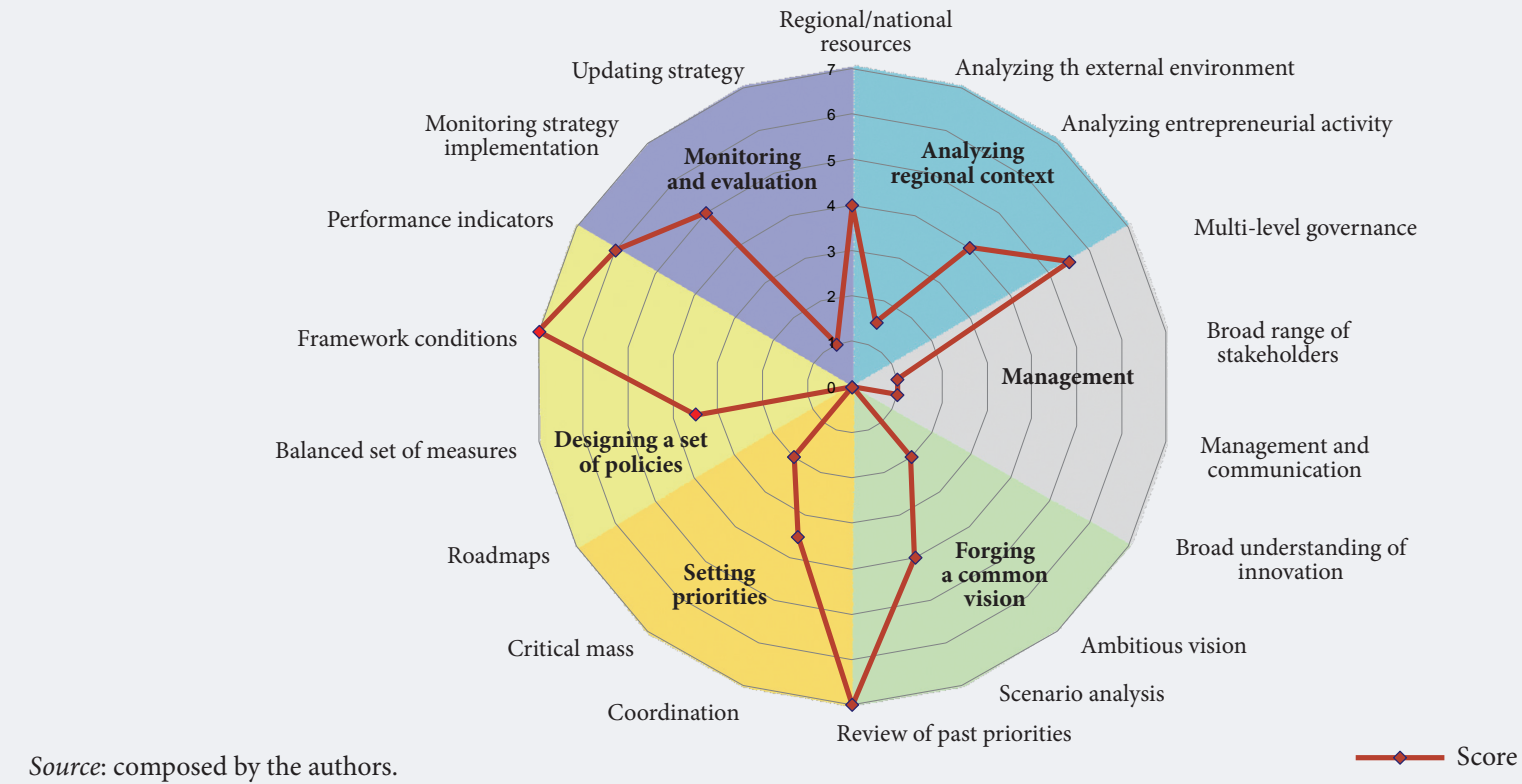

Source: composed by the authors.

\footnotetext{
${ }^{15}$ The RRII differentiation is calculated as the ratio of RRII values of the sample's leader (Tatarstan, 0.5625) and the region at the bottom of the ranking (the Ingush Republic, 0.1909) and was 2.94.
} 


\section{Table 5. Assessment of Russian Regional Innovation Development Strategies'} Matching Smart Specialisation Criteria

\begin{tabular}{|c|c|c|c|c|c|c|c|c|}
\hline \multirow{2}{*}{ No. } & \multirow[t]{2}{*}{ Criterion } & \multicolumn{7}{|c|}{$\begin{array}{c}\text { Assessment of Russian regional innovation development } \\
\text { strategies' matching smart specialization criteria }\end{array}$} \\
\hline & & $\mathbf{I}$ & II & III & IV & V & VI & VII \\
\hline \multicolumn{9}{|c|}{ Step 1. Analysing regional context } \\
\hline 1. & Analyzing regional resources & 0.5 & 0.5 & 1 & 1 & 1 & 0.5 & 0.5 \\
\hline 2. & Analyzing external environment & 0 & 0 & 1 & 0 & 0 & 0 & 0 \\
\hline 3. & Analyzing entrepreneurial activity & 0.5 & 0 & 1 & 1 & 0 & 0 & 0.5 \\
\hline \multicolumn{9}{|c|}{ Step 2. Management } \\
\hline 4. & Putting into place a multilevel management system & 0 & 1 & 0.5 & 0.5 & 0.5 & 0.5 & 0.5 \\
\hline 5. & Involving a wide range of stakeholders & 0.5 & 0.5 & 1 & 0 & 0 & 0 & 0 \\
\hline 6. & Developing management and communication techniques & 0.5 & 0.5 & 0.5 & 0.5 & 0.5 & 0.5 & 1 \\
\hline \multicolumn{9}{|c|}{ Step 3. Common vision } \\
\hline 7. & Using a broad understanding of innovation & 0.5 & 0 & 0 & 0 & 0 & 0 & 0 \\
\hline 8. & Addressing global challenges & 0.5 & 0 & 0 & 0 & 1 & 0 & 0 \\
\hline 9. & Using scenario analysis & 0 & 1 & 1 & 0.5 & 1 & 0 & 1 \\
\hline \multicolumn{9}{|c|}{ Step 4. Priorities } \\
\hline 10. & Setting priorities & 1 & 1 & 1 & 1 & 1 & 1 & 1 \\
\hline 11. & Coordinating priorities & 0 & 0 & 1 & 0.5 & 0.5 & 0.5 & 0 \\
\hline 12. & Achieving critical mass & 0.5 & 0 & 1 & 0.5 & 0 & 0 & 0 \\
\hline \multicolumn{9}{|c|}{ Step 5. Policies } \\
\hline 13. & Using roadmaps & 0 & 0 & 0 & 0 & 0 & 0 & 0 \\
\hline 14. & Implementing a balanced set of measures & 1 & 0 & 1 & 1 & 1 & 0 & 0.5 \\
\hline 15. & Creating adequate framework conditions & 1 & 1 & 1 & 1 & 1 & 1 & 1 \\
\hline \multicolumn{9}{|c|}{ Step 6. Monitoring and evaluation } \\
\hline 16. & Using performance indicators & 1 & 1 & 1 & 1 & 1 & 1 & 1 \\
\hline 17. & Strategy implementation monitoring system & 1 & 1 & 0 & 0 & 1 & 1 & 1 \\
\hline 18. & Mechanism for updating the strategy & 0 & 0.5 & 0 & 0 & 1 & 0 & 0 \\
\hline \multicolumn{9}{|c|}{$\begin{array}{l}\text { Note: I — Ingush Republic; II — Republic of Tatarstan; III — Sverdlovsk Region; IV — Stavropol Region; V — Kamchatka Region; VI - Krasnoyarsk } \\
\text { Region; VII - Chelyabinsk Region. }\end{array}$} \\
\hline
\end{tabular}

Despite having similar patterns of strengths and weaknesses, these innovation strategies differ in specific smart specialization criteria. For example, the Ingush Republic's strategy, unlike the Tatarstan's, places an emphasis upon promoting entrepreneurial activity (analysis and priority setting), using a broad understanding of innovation, applying it to address global challenges, and balancing horizontal and precision support measures. Meanwhile, Tatarstan's strategy makes provisions for a multilevel management system, scenario analysis, and an updating mechanism.

The identified differences between the strategies regarding smart specialization criteria (which can be described as subjective) only partially match the objective indicators of the regions' innovation development level (as measured by the RRII).

For example, in terms of providing organizational support for innovation policy, the Republic of Tatarstan is the national leader, while the Ingush Republic holds $61^{\text {st }}$ place in the ranking (zero value of this parameter). Another example: the Ingush Republic's innovation strategy does not specifically describe businesses as active participants in innovative activities. This region has zero values for all indicators that are used to calculate the Innovation Activities of Organizations sub-index [HSE, 2016].

\section{Testing Hypothesis 2}

The analysis of the strategies included in the sample revealed that all these documents formally meet the "Setting priorities" and "Using performance indicators" criteria. Therefore, at the next step of the study, we checked the validity of the selected regional specialization industries and the adequacy of the applied performance indicators. Figure 8 shows the frequency of mentioning various industries as priority ones in Russian regions' innovation strategies.

To assess validity of the selected priorities, the sectors' relative weight in the national and regional economy was calculated. Conducting an integrated analysis and preparing recommendations for specific regions goes beyond the scope of this study, so we used only the most common indicators and assessment techniques. 
Figure 4. Distribution of Russian Regional Innovation Strategies' Evaluation Results by Strategy Development Steps

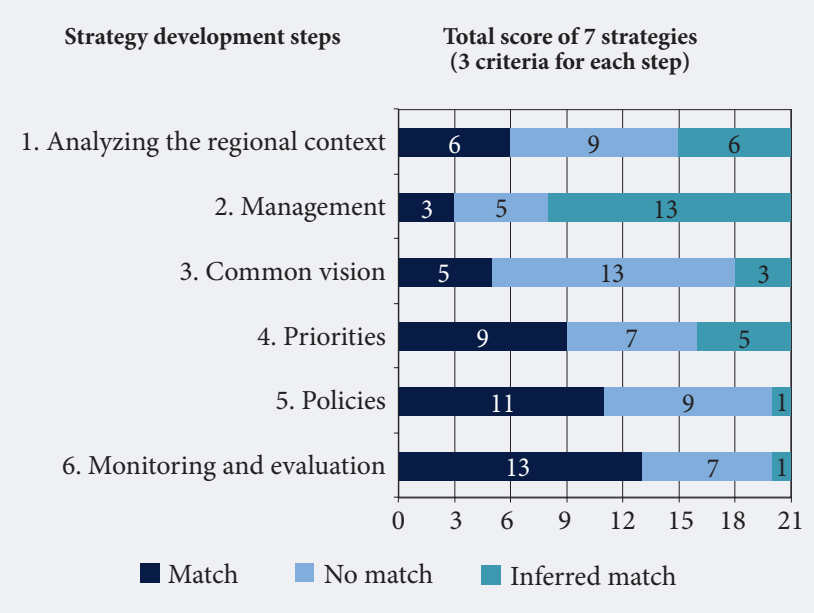

Source: composed by the authors.
Figure 5. Comparison of Russian Regions' Innovation Development Rankings with the Number of Smart Specialization Criteria Their Innovation Strategies Match

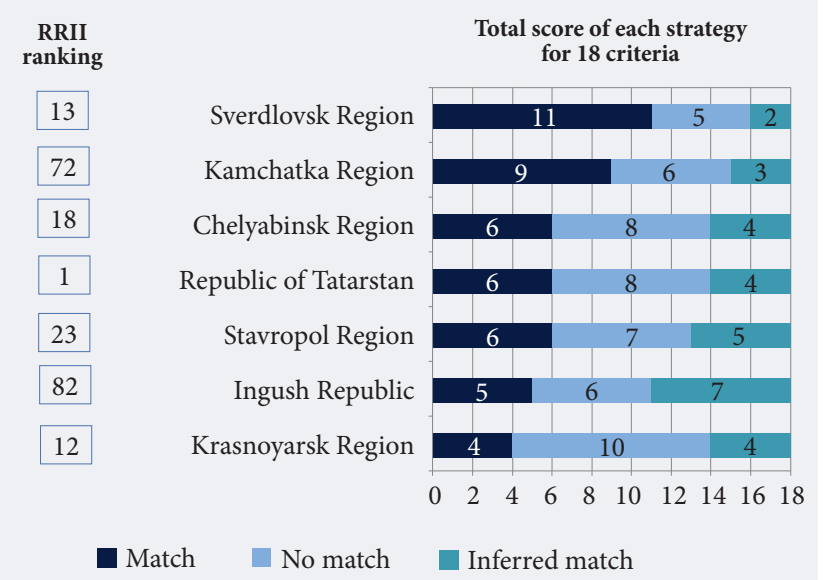

Source: composed by the authors based on [HSE, 2016].

The test analysis covered two sectors: ICT and the nanotechnology industry (Figures 9 and 10). Other industries selected as strategic priorities were not considered. The reason was that in most cases they were obvious choices determined by the regions' traditional specialization (e.g., agriculture in the Stavropol Region, tourism in the Ingush Republic and Kamchatka Region), or alternatively, there were no established economic activities in the region (and, accordingly, no relevant statistical data was available) in such areas as biomedicine or energy efficiency.

In only one out of the five regions that have set the ICT sector as an innovation development priority was this industry's development level higher than the Russian average (in the Republic of Tatarstan). In other regions, this indicator was below the national average value and in some regions, it was even below the average for the relevant federal district, which, in our opinion, puts the decision to set it as a priority in doubt.

The situation with the nanotechnology industry is quite different: its choice as a priority area by two regions out of three (Sverdlovsk and Chelyabinsk Regions) seems to be valid, although Tatarstan (which

\section{Figure 6. Evaluation of the Strategy for Development of Innovation and Research Activities in the Republic of Tatarstan until 2015 for Matching Smart Specialization Criteria}

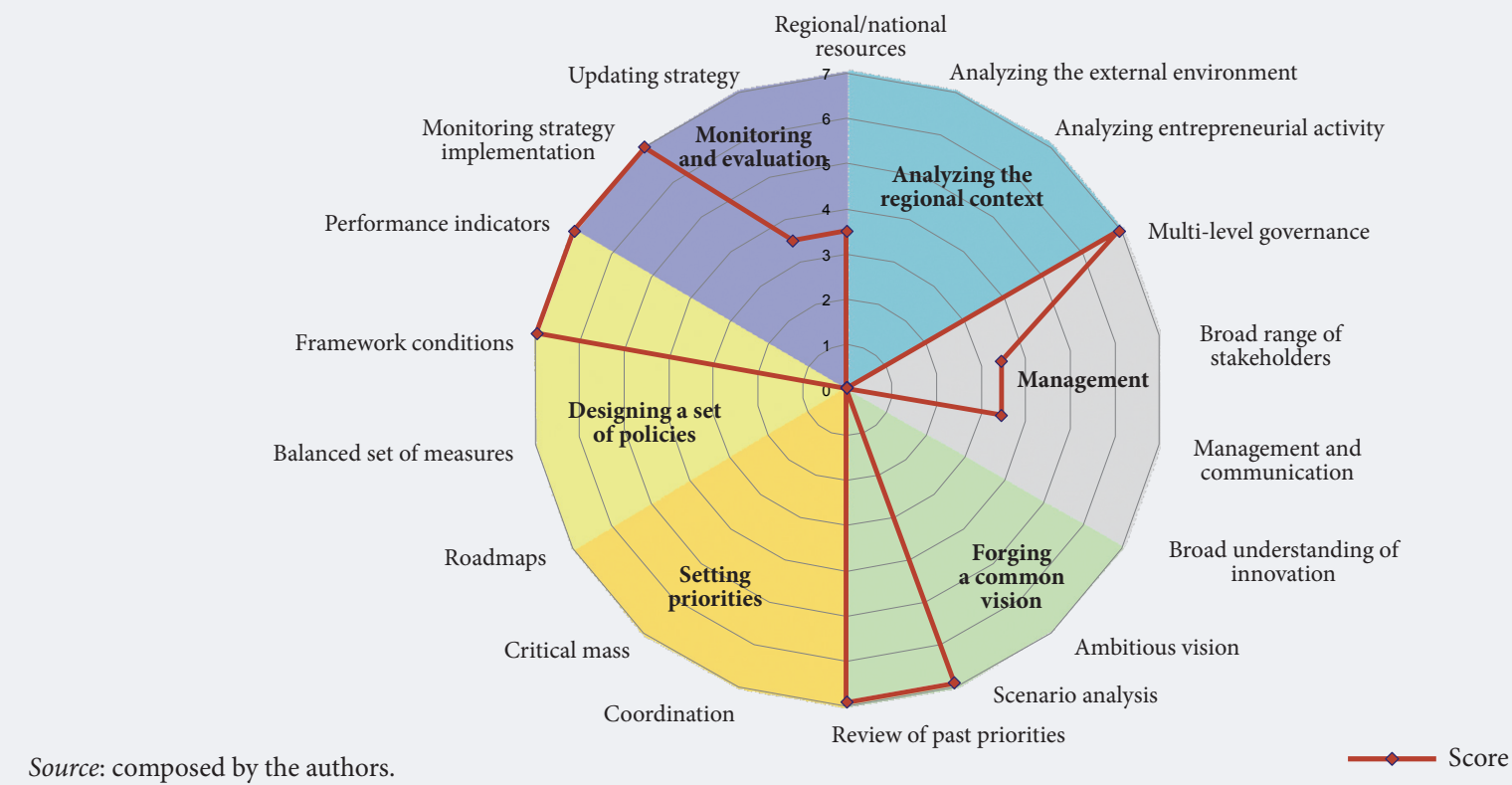



until 2015 for Matching Smart Specialization Criteria

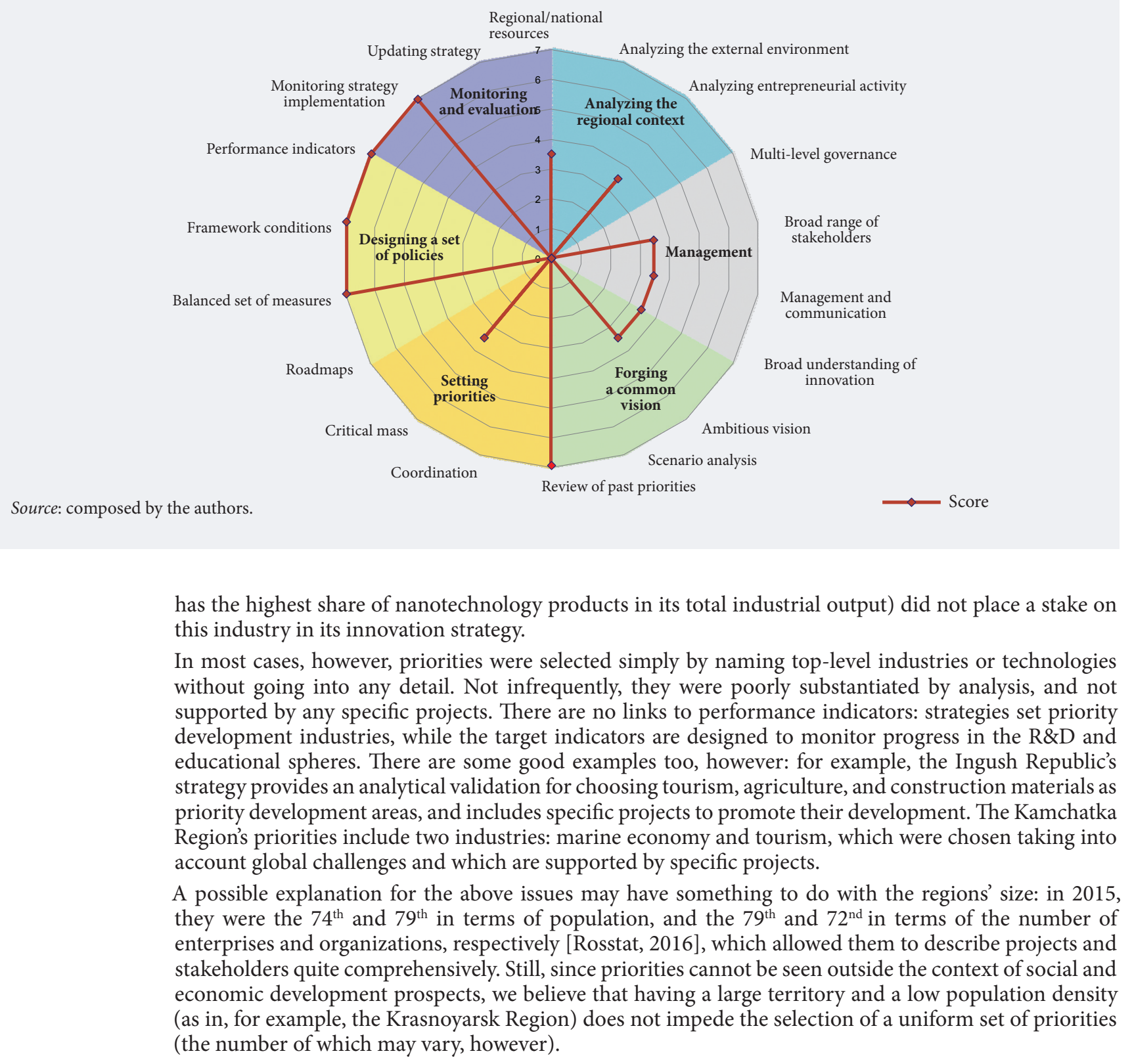

Figure 8. Frequency of Mentioning Sectors of the Economy as Priority Ones in Russian Regions' Innovation Strategies

ICT

Energy, energy efficiency, alternative energy sources

Nanotechnology

Medicine, bio- and translational medicine, pharmaceutics, pharmacology

Agriculture and fisheries

Tourism

Environment protection technologies

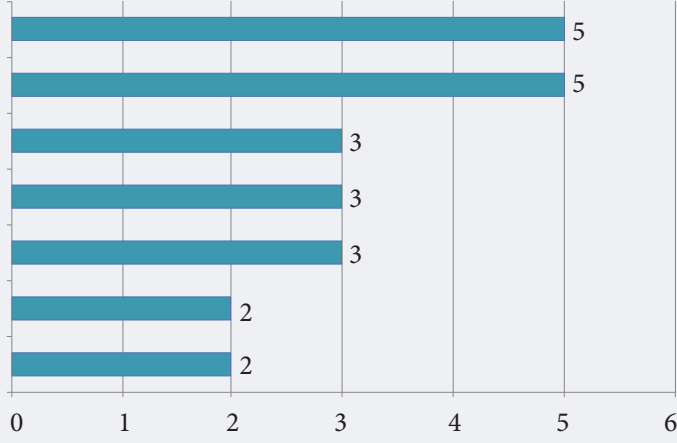

Number of strategies highlighting the industry as a priority 


\section{Figure 9. Average Number of Regional ICT Companies' Employees as a Percentage} of the Total Regional Workforce
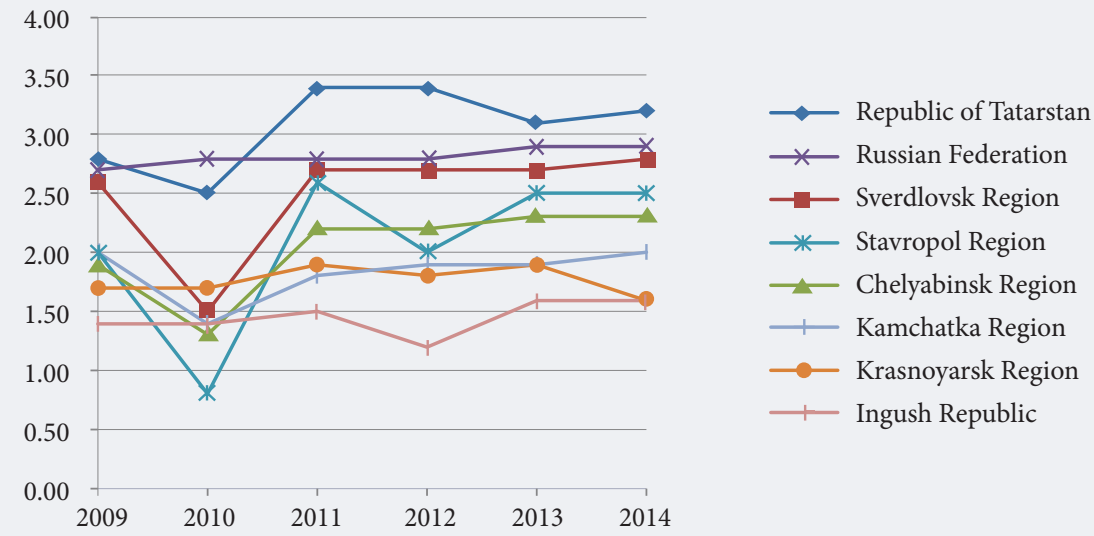

Note: Regions which have specified ICT as a priority innovation development area include the Republic of Tatarstan, Sverdlovsk Region, Chelyabinsk Region, Krasnoyarsk Region, and the Ingush Republic.

Source: composed by the authors based on Rosstat data.

Performance indicators are also formally present in each of the innovation strategies under consideration. However, in most cases they are not linked with the priority industries and are usually intended for monitoring the development of the R\&D sector. An exception is the Ingush Republic where education is set as a priority area, with relevant performance indicators suggested for it. Also, the performance indicators mentioned in the strategies are quite numerous (up to 29), while a lack of hierarchy hinders setting targets and evaluating results. Frequently performance indicators are described in very general terms, which are also different from the established statistical standards (e.g., "gross added value in the innovative sector as a share of the gross regional product" or "the creation of innovative enterprises"). This reduces their analytical value, due to the lack of a common data collection and verification methodology, and the incompatibility with other regional and national figures.

Figure 11 shows the distribution of performance indicators included in the strategies under consideration, grouped in line with the RRII sub-index classification [HSE, 2016]. Most of the performance indicators describe the state and development level of the R\&D sphere, relevant results and S\&T potential, or innovation activities of regional companies and organizations. However, despite the fact that each regional strategy describes framework conditions for innovation, only in two cases were the latter linked with the socioeconomic situation.

Figure 10. Share of Nanotechnology-related Shipped In-house Manufactured Products and Provided Services in the Total Volume of Shipped Products (\%)

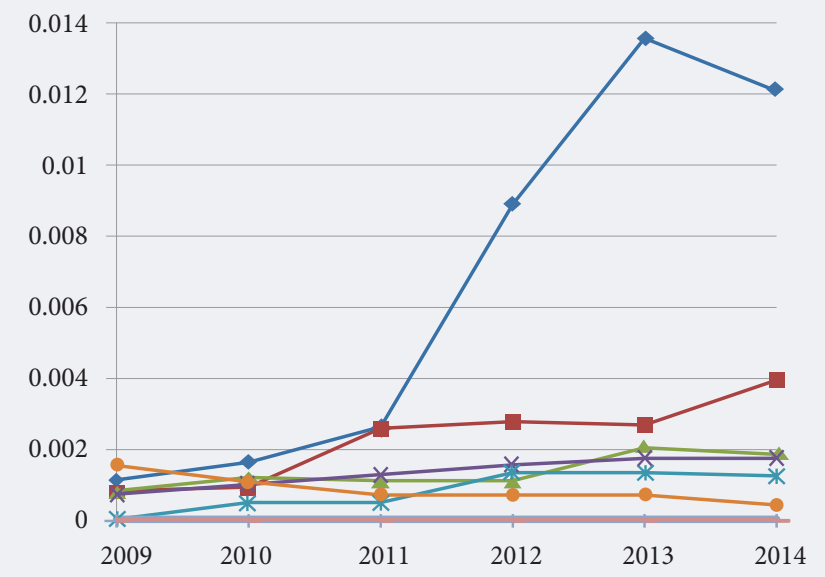

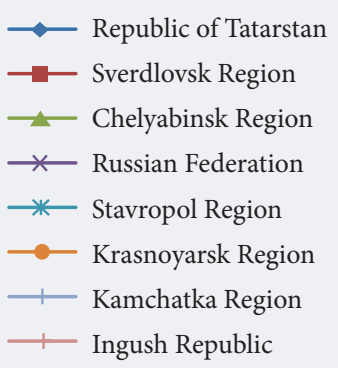

Note: Regions which have specified nanotechnology as a priority innovation development area include: Sverdlovsk Region, Chelyabinsk Region, Stavropol Region.

Source: composed by the authors based on Rosstat data. 


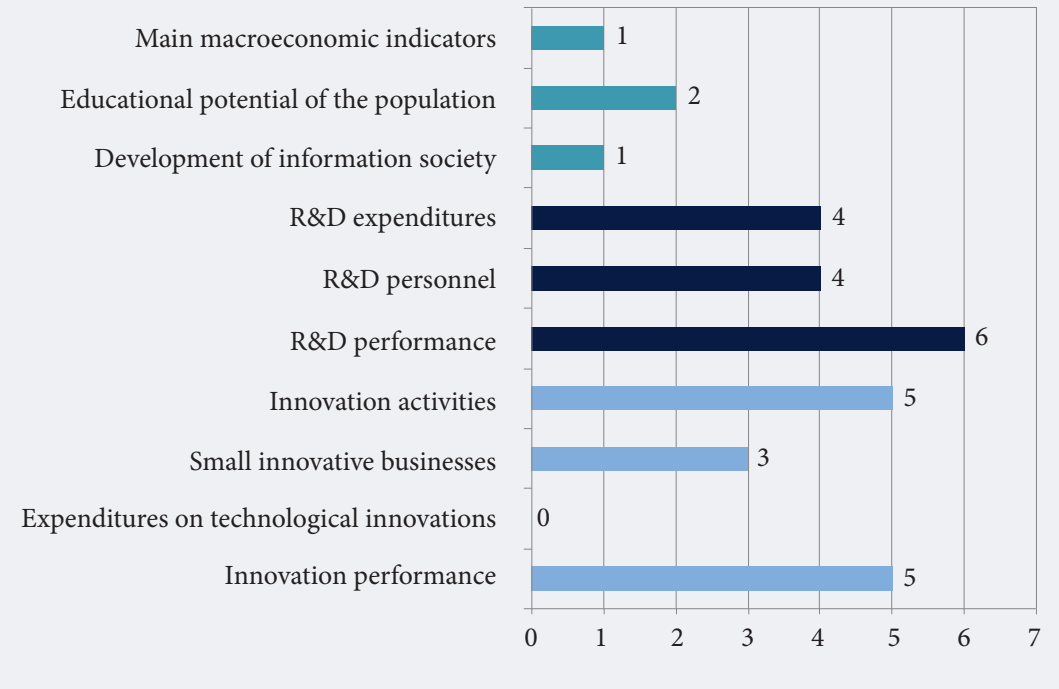

Main macroeconomic indicators
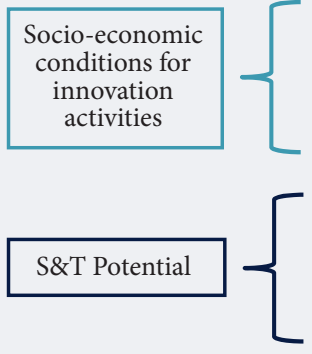

Innovation activities

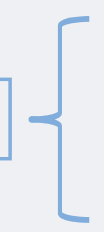

Small innovative businesses

Innovation performance

0

\section{Summary and Recommendations}

The assessment of innovation strategies' matching smart specialization criteria confirmed the first hypothesis that regional innovation strategies were designed without taking this concept into account, though they still feature some of its characteristics. Each strategy includes the following elements: an analysis of the local context, mechanisms for program development and implementation, visions of innovation development prospects, relevant priorities, policies, and performance indicators.

In terms of the six steps described in the Guide, the high scores for some of these criteria are accompanied by low scores for others. The strategies' weaknesses include the following:

- Poor analytics. Only two of the seven strategies include a SWOT analysis. Most of the documents do not take into account the external environment, i.e., other regions' strengths and specialization industries. It leads one to believe that innovation priorities were frequently set blindly, without inter-regional comparison. The exception is the Sverdlovsk Region's strategy which includes a benchmarking with other regions with a description of the applied methodology.

- Poor management mechanisms. Almost all the regions lack structures responsible for strategy development and implementation. Typically, an official or a regional executive agency performs these functions. Only in the Republic of Tatarstan does the Presidium of the Republican Academy of Sciences along with the Cabinet of Ministers have relevant management responsibilities. Also, most of the documents did not mention that a broad range of stakeholders was involved in their development and implementation. Only in the Sverdlovsk Region and Ingush Republic were businesses named as active participants in innovation activities. In the first case, innovative development priorities were set on the basis of an enterprise survey and in the second, taking into account innovative projects implemented by local entrepreneurs.

- Using a broad understanding of innovation. This is one of the more commonly ignored requirements of the smart specialization concept, which implies taking into account various forms of innovation activities. Most of the regional strategies are based on a linear innovation model. For example, the Sverdlovsk regional strategy says that "breaking the innovation chain at any stage limits the scope for innovation-based economic development" [p. 13]. At the same time, innovation in locallyspecific activity types can be no less important for the successful development of the economy (e.g., outpatient medicine, retail, social services, culture and recreation, and communal services).

Changing employment models, family relations, and lifestyles promote demand for products and services previously produced by the consumers themselves. Increased life expectancy and advances in healthcare technologies promote the growth of various segments of the medical services market. Investments in improving the quality of life create conditions for consumption-based economic growth. The diverse supply of non-market products in specific regions is becoming an attractive factor, which is manifested through increased employment and purchasing power [Markusen, 2007; Nelson, 1997].

The results of the study indicate that in smart specialization terms, the regional innovation strategies seem to be more declarative than practical. No strategy contains roadmaps and most of them lack mechanisms for updating priorities and support policies. An exception is the Kamchatka strategy, which specifies that the regional Ministry of Education and Science must annually conduct an analysis of the actual level of innovation activities and adjust the relevant priorities. 
Performance indicators are mostly oriented towards monitoring progress in the R\&D sector. Innovation priorities are formulated without consideration of the smart specialization principles, i.e., they do not merge traditional economic specialization areas with new emerging S\&T areas or imply an orientation towards structural changes in the economy and in future markets. Even regions with high innovative potential, whose strategies formally do match most of the Guide's requirements, cannot ensure that smart specialization ideas will be conceptually implemented.

The best and worst (in terms of meeting smart specialization criteria) innovation strategies have similar weaknesses, and on the whole can be described as fragmentary. The documents' quality does not always directly reflect the regions' innovative potential, which can speed up the implementation of the latter in future. However, this requires meeting not just some criteria, but the whole range of them. The strength of the smart specialization approach lies exactly in its integrated nature, i.e., in the need to apply all the tools simultaneously, each of which was "invented" before the concept actually emerged. Without taking into account the whole set of the interlinked criteria it would be difficult to act systemically, which is a condition of the strategy actually affecting the development of innovation. Similar patterns of strengths and weaknesses of strategic planning noted in totally different regions indicate that there is a single factor in place that determines this common style of strategizing generally, and its typical flaws in particular. We mean the lack of a top-level system which would impose standardized rules for setting, verifying, and synchronizing priorities, and provide organizational support for designing and implementing the regional innovation development strategies.

It can be noted that due to its ontological relativity, the "smart/unique" category is better suited to describe not regional strategies, but those adopted by a whole system of regions (e.g., those registered on the EU Smart Specialisation Platform). This can be interpreted as follows: it is rather difficult to be "smart on one's own" and identify industries or technology areas to achieve supremacy in without taking into account the specialization areas, strengths, and strategies of other regions. So, our second hypothesis that achieving valid comparability and successfully dealing with regional priority duplication and fragmented support initiatives issues requires higher-level (national or supra-national) organizational solutions, is also confirmed.

Such solutions may include the following:

- a database of priorities and projects;

- interactive tools for comparing regions by a wide range of parameters;

- standardized priority-setting rules based on a unified system of classifiers (while strategy development should be delegated to regions);

- methodological and expert support for regional teams (methodological recommendations, best practice handbooks, training, internships);

- mechanisms for regions to review and discuss their S\&T and industrial development priorities, for the subsequent centralized approval of strategies through open expert evaluation and "defense" procedures.

It would make sense to integrate such organizational solutions into the smart specialization concept, along with the existing detailed methodological recommendations in the Guide. Meeting some of the specific smart specialization requirements does not really make strategies smart and no public administration level has priority over others. More importantly, their interaction should be analyzed, along with the interaction of the same-level agencies, including various initiatives, formats, regularity, etc. The national (supra-national) level must be a participant in such a dialogue and, in some cases, act as an initiator or organizer, for example, regarding inter-regional cooperation.

Taking the aforementioned organizational solutions further, one comes to the following dilemma. On the one hand, the more regions the system includes, the wider is the scope for benchmarking, identifying unique priorities, and developing high-quality strategies. Accordingly, the existing EU Smart Specialisation Platform may evolve towards growth by integrating new regions located in non-member countries (Norwegian, Turkish, Serbian, and Moldovan regions are already registered on the Platform), and the emergence of a global "smart system". An alternative scenario would be setting up similar systems in nation states with a larger number of regions (e.g., Russia, US, China), or in economic alliances (EAEU, MERCOSUR, NAFTA, etc.), which subsequently may synchronize with one another.

On the other hand, the need to eliminate priority duplication can potentially lead to reduced competition between regions, which would negatively affect the quality of products and services produced in numerous unique industries. In that case, a possible solution would be preserving certain duplication of specialization areas, and therefore competition, as a condition of the smart system's sustainability.

\section{Conclusion}

This paper analyzes the scope for applying the smart specialization concept in individual regions of countries outside the EU using Russia as an example. Smart specialization is a scientific concept and at the same time a methodological approach to designing regional innovation strategies adopted by the 
EU to reconcile the logic of two government policies. This approach implies establishing standardized conditions for setting national-level innovation priorities. Thus, it solves the problem of duplicating competences and regional support initiatives implemented in various countries. Delegating strategy development and implementation responsibilities from the national to regional level of governance reduces the risks of choosing the wrong specialization areas. From 2009 onwards, smart specialization was actively used in the EU. A central institution was set up, the Smart Specialisation Platform. It helps synchronize regional innovation strategies, sets a framework for identifying regions' unique competitive advantages, and provides them methodological and instrumental support.

The analysis of seven innovation development strategies adopted by Russian regions revealed that all of them featured certain elements of the smart specialization concept (such as selecting priority industries for applying innovations, monitoring results using performance indicators, and creating framework conditions).

At the same time, it should be recognized that designing regional innovation development strategies does not yet have a proper analytical basis in Russia; stakeholders become involved in priority setting only sporadically, while innovations are considered independent of the socioeconomic context.

Some provisions of the smart specialization concept are inherent to high-quality strategies and their application does not require a new synthetic model (such as smart specialization) or special mechanisms in the form of methodological recommendations, platforms, and organizational structures. At the same time, while formally meeting a number of important criteria described in the Guide, regional strategies may fail to accomplish their main objective: mapping the "unique development path" for the region. No clear links between regions' innovation activities and the quality of their innovative strategies in terms of smart specialization was revealed. Apparently, designing a smart specialization strategy at the level of a specific region still remains a formidable task. It requires external knowledge: comparable data about other regions, national priorities and initiatives, and global technology trends. Accordingly, a (supra)nationallevel approach should be adopted, along with developing standardized rules for setting, verifying, and synchronizing priorities, unifying the available analytical database, and providing organizational support to promote the emergence of a common economic and research area in one or more countries. Thus, the smart specialization concept should be imported into countries outside the EU systematically, involving not only the regional but also national authorities in the process, and potentially, the regional alliances of countries. This is the way to most productively apply the smart specialization concept.

The article was prepared within the framework of the Basic Research Program at the National Research University Higher School of Economics (HSE) and supported within the framework of a subsidy by the Russian Academic Excellence Project '5-100'. The authors are sincerely grateful for the help in the calculations of statistical indicators to colleagues from the HSE Institute for Statistical Studies and Economics of Knowledge: Gulnara Abdrakhmanova (Director of the Centre for Statistics and Monitoring of Information Society), Galina Kovaleva (Chief Expert of the Centre for Statistics and Monitoring of Information Society), and Elena Nechaeva (Director of the Centre for Processing Social and Economic Information).

\section{References}

Asheim B., Isaksen A. (1997) Location, agglomeration and innovation: Towards regional innovation systems in Norway? European Planning Studies, vol. 5, no 3, pp. 299-330.

Asheim B., Isaksen A. (2002) Regional innovation systems: The integration of local 'sticky' and global 'ubiquitous' knowledge. Journal of Technology Transfer, vol. 27, no 1, pp. 77-86.

Barca F. (2009) Agenda for a Reformed Cohesion Policy, Brussels: European Parliament. Available at: http://www. europarl.europa.eu/meetdocs/2009_2014/documents/regi/dv/barca_report_/barca_report_en.pdf, accessed 05.03.2017.

Barca F., McCann P., Rodríguez-Pose A. (2012) The case for regional development intervention: Place-based versus place-neutral approaches. Journal of Regional Science, vol. 52, no 1, pp. 134-152.

Barceló M., Abel I., Fuster E., Marrugat N., Ordenes A., Hernández N., Santarremigia E., Pujolar A., Sánchez D. (2015) EU-Latin America cooperation on regional innovation strategies in the framework of regional policy, Brussels: European Commission. Available at: http://ec.europa.eu/regional_policy/sources/cooperate/international/pdf/ final_report_ris_latam_en.pdf, accessed 15.09.2017.

Bellini N., Landabaso M. (2007) Learning about innovation in Europe's regional policy. The Learning Region: Foundations, State of the Art, Future (eds. R. Rutten, F. Boekema), Cheltenham: Edward Elgar, pp. 231-251.

Boschma R. (2014) Constructing regional advantage and smart specialisation: Comparison of two European policy concepts. Scienze Regionali, vol. 13, no 1, pp. 51-68.

Boschma R., Iammarino S. (2009) Related variety, trade linkages, and regional growth in Italy. Economic Geography, vol. 85, no 3, pp. 289-311.

Camagni R. (1995) The concept of "innovative milieu" and its relevance for public policies in European lagging regions. Papers in Regional Science, vol. 74, no 4, pp. 317-340. 
Capello R. (2014) Smart specialisation strategy and the new EU cohesion policy reform: Introductory remarks. Scienze Regionali, vol. 13, no 1, pp. 5-15.

Capello R., Kroll H. (2016) From theory to practice in smart specialization strategy: Emerging limits and possible future trajectories. European Planning Studies, vol. 24, no 8, pp. 1393-1406.

Charles D., Nauwelaers C., Mouton B., Bradley D. (2000) Assessment of the regional innovation and technology transfer strategies and infrastructures (RITTS) scheme, Luxembourg: CEC.

Coffano M., Foray D. (2014) The centrality of entrepreneurial discovery in building and implementing a smart specialisation strategy. Scienze Regionali, vol. 13, no 1, pp. 33-50.

Cooke P. (1992) Regional innovation systems: Competitive regulation in the new Europe. Geoforum, vol. 23, no 3, pp. 365-382.

Cooke P. (1999) Local learning and interactive innovation networks in a global economy. Making Connections: Technological Learning and Regional Economic Change (eds. E. Malecki, P. Oinas), Aldershot: Ashgate, pp. 145-178.

Cooke P. (2002) Regional innovation systems: General findings and some new evidence from biotechnology clusters. The Journal of Technology Transfer, vol. 27, no 1, pp. 133-145.

Del Castillo H.J., Elorduy J. (2016) Smart specialisation across the world: The case of Latin America. Paper presented at the 1st SMARTER Conference on Smart Specialisation and Territorial Development. Available at: http://www. regionalstudies.org/uploads/CastilloPaton_INGLES.pdf, accessed 22.02.2017.

Doloreux D. (2004) Regional networks of small and medium sized enterprises: Evidence from the Metropolitan Area of Ottawa in Canada. European Planning Studies, vol. 12, no 2, pp. 173-189.

Edmondson G., McCollam S., Kelly E. (2014) 5 Steps to Smarter Specialisation. A briefing note on innovation investments to be made under the European Commission's new cohesion policy, Brussels: Science Business Publishing Ltd. Available at: http://know-hub.eu/static/global/media_catalog/2014/03/28/193/original.pdf, accessed 22.02.2017.

Estensoro M., Larrea M. (2016) Overcoming policy making problems in smart specialization strategies: Engaging subregional governments. European Planning Studies, vol. 24, no 7, pp. 1319-1335.

EU CoR (2016) Regional Innovation Ecosystems. CoR Guide: Learning from the EU's Pioneering Cities and Regions, Brussels: European Union Committee of the Regions. Available at: http://cor.europa.eu/en/documentation/ brochures/Documents/Regional-innovation-ecosystems/Regional-innovation-ecosystems.PDF, accessed 22.02.2017.

European Commission (2009) The Role of Community Research Policy in the Knowledge-Based Economy. Expert group report, Brussels: European Commission. Available at: http://ec.europa.eu/research/era/pdf/community_research_ policy_role.pdf, accessed 22.02.2017.

European Commission (2010) Regional Policy Contributing to Smart Growth in Europe 2020. Communication from the Commission to the European Parliament, the Council, the European Economic and Social Committee and the Committee of the Regions (COM (2010) 553 final), Brussels: European Commission. Available at: http://ec.europa. eu/regional_policy/sources/docoffic/official/communic/smart_growth/comm2010_553_en.pdf, accessed 05.11.2015.

European Commission (2012) Guide to Research and Innovation Strategies for Smart Specialisations, Brussels: European Commission. Available at: http://s3platform.jrc.ec.europa.eu/documents/20182/84453/RIS3+Guide. pdf/fceb8c58-73a9-4863-8107-752aef77e7b4, accessed 30.03.2016.

European Commission (2016a) European structural and investment funds, Brussels: European Commission. Available at: http://ec.europa.eu/contracts_grants/funds_en.htm, accessed 22.02.2017.

European Commission (2016b) Smart Specialisation Platform, Brussels: European Commission. Available at: http:// s3platform.jrc.ec.europa.eu/, accessed 30.03.2016.

European Parliament (2013) The Regulation (EU) 1303/2013 of the European Parliament and of the Council of 17 December 2013. Official Journal of the European Union, no 347, pp. 320-469. Available at: http://eur-lex. europa.eu/legal-content/EN/TXT/PDF/?uri=CELEX:32013R1303\&from=en, accessed 22.02.2017.

Eurostat (2016) Population on 1 January. Available at: http://ec.europa.eu/eurostat/tgm/table.do?tab=table\&languag $\mathrm{e}=\mathrm{en} \&$ pcode=tps00001\&tableSelection=1\&footnotes=yes\&labeling=labels\&plugin=1, accessed 22.02.2017.

Florida R. (1995) Toward the Learning Region. Futures, vol. 27, no 5, pp. 527-536.

Foray D. (2013) Smart Specialisation and the New Industrial Policy Agenda. Paper presented at the 2013 ERAC Mutual Learning Seminar, 20th March 2013. Available at: https://era.gv.at/object/document/360/attach/industrial_policy_ agenda.ppt, accessed 18.01.2018.

Foray D., David P., Hall B. (2009) Smart specialization - The concept. Knowledge Economists Policy Brief, vol. 9 , no 85, pp. 1-5. Available at: http://ec.europa.eu/invest-in-research/pdf/download_en/kfg_policy_brief_no9.pdf, accessed 18.01.2018.

Foray D., David P., Hall B. (2011) Smart specialisation from academic idea to political instrument, the surprising career of a concept and the difficulties involved in its implementation (MTEI-WORKING_PAPER-2011-001), Lausanne: École polytechnique fédérale de Lausanne.

Foray D., Goenaga X. (2013) The goals of smart specialization, Luxembourg: Publications Office of the European Union.

Foray D., van Ark B. (2007) Smart specialisation in a truly integrated research area is the key to attracting more R\&D to Europe. Knowledge Economists Policy Brief, vol. 1, pp. 1-4. Available at: http://ec.europa.eu/invest-in-research/ pdf/download_en/policy_brief1.pdf, accessed 18.01.2018. 
Formaini R.L. (2004) David Ricardo Theory of Free International Trade. Economic Insights. Bulletin of the Federal Reserve Bank of Dallas, vol. 9, no 2, pp. 1-4. Available at: https://www.dallasfed.org/assets/documents/research/ ei/ei0402.pdf, accessed 22.02.2017.

Frenken K., van Oort F., Verburg T. (2007) Related variety, unrelated variety and regional economic growth. Regional Studies, vol. 41, no 5, pp. 685-697.

Gianelle C., Kleibrink A. (2015) Monitoring Mechanisms for Smart Specialisation Strategies (JRC Technical Report 13/2015), Seville: JRC-IPTS. Available at: http://s3platform.jrc.ec.europa.eu/documents/20182/114948/JRC95458_ Monitoring_Mechanisms_S3_Policy_Brief.pdf/ce74fd68-cd17-4574-950d-4551582655d2, accessed 22.02.2017.

Giannitsis T. (2009) Technology and specialisation: Strategies, options and risks. Knowledge Economists Policy Brief, no 8 , pp. 25-30.

Glaeser E., Berry C. (2006) Why are smart places getting smarter. Taubman Center Policy Brief, no 2, pp. 1-4. Available at: https://www.hks.harvard.edu/sites/default/files/centers/rappaport/files/brief_divergence.pdf, accessed 15.09.2017.

Goddard J., Kempton L., Vallance P. (2013) Universities and Smart Specialisation: Challenges, Tensions and Opportunities for the Innovation Strategies of European Regions. Ekonomiaz, vol. 83, no 2, pp. 83-102.

Hausmann R., Rodrik D. (2003) Economic development as self-discovery. Journal of Development Economics, vol. 72, no 2, pp. 603-633.

Hidalgo C., Hausmann R. (2009) The building blocks of economic complexity. Proceedings of the National Academy of Sciences, vol. 106, no 26, pp. 10570-10575.

Hollands R. (2008) Will the real smart city please stand up? Intelligent, progressive or entrepreneurial? City, vol. 12, no 3, pp. 303-320.

HSE (2016) Reiting innovatsionnogo razvitiya sub"ektov Rossiiskoi Federatsii [The Rating of Innovative Development of the Subjects of the Russian Federation], issue 4. (ed. L. Gokhberg), Moscow: HSE (in Russian).

Hughes A. (2012) Choosing Races and Placing Bets: UK National Innovation Policy and the Globalisation of Innovation Systems. The UK in a Global World: How Can the UK Focus on Steps in Global Value Chains that Really Add Value? (ed. D. Greenaway), London: CEPR, pp. 37-70.

Iacobucci D. (2014) Designing and implementing a smart specialisation strategy at regional level: Some open questions. Scienze Regionali, vol. 13, no 1, pp. 107-126.

Iacobucci D., Guzzini E. (2016) Relatedness and connectivity in technological domains: Missing links in S3 design and implementation. European Planning Studies, vol. 24, no 8, pp. 1511-1526.

International Monetary Fund (2016) Report for Selected Country Groups and Subjects. Available at: http://bit. ly/2mY2bpl, accessed 22.02.2017.

IRE Working Group (2008) Effective regional innovation systems: Final working group report, Luxembourg: IRE Secretariat.

Ketels C., Peck F., Lindqvist G., Lubicka B., Nauwelaers C., Harper J. (2013) The role of clusters in smart specialisation strategies, Brussels: ERDF.

Kroll H. (2015) Efforts to implement smart specialization in practice - Leading unlike horses to the water. European Planning Studies, vol. 23, no 10, pp. 2079-2098.

Kroll H., Muller E., Schnabl E., Zenker A. (2014) From smart concept to challenging practice - How European regions deal with the commission's request for novel innovation strategies (Working Paper Policy and Region R2/2014), Karlsruhe: Fraunhofer ISI.

Landabaso M. (2014) Time for the real economy: The need for new forms of public entrepreneurship. Italian Journal of Regional Science, vol. 13, no 1, pp. 127-140.

Landabaso M., Oughton C., Morgan K. (1999) Learning Regions in Europe: Theory, Policy and Practice Through the RIS Experience. Paper presented at the 3rd International Conference on Technology and Innovation Policy, August 30 - September 2, Austin, TX.

Larsen P. (2011) Cross-sectoral analysis of the impact of international industrial policy on key enabling technologies, Brussels: European Commission. Available at: https://publications.europa.eu/en/publication-detail/-/ publication/713f63c6-9d8a-4680-99f3-de63d489e79e, accessed 22.02.2017.

Maillat D. (1997) From the industrial district to the innovative milieu: Contribution to an analysis of territorialized productive organizations (WP 9606b), Neuchâtel: Institut de Recherches Economiques et Régionales, Université de Neuchâtel.

Markusen A. (2007) A consumption base theory of development: An application to the rural cultural economy. Agricultural and Resource Economics Review, vol. 36, no 1, pp. 9-23.

McCann P., Ortega-Argilés R. (2011) Smart specialisation, regional growth and applications to EU cohesion policy. Documents de Treball IEB, no 14, pp. 1-32.

McCann P., Ortega-Argilés R. (2014) Smart specialisation in European regions: Issues of strategy, institutions and implementation. European Journal of Innovation Management, vol. 17, no 4, pp. 409-427.

McCann P., Ortega-Argilés R. (2015) Smart specialization, regional growth and applications to European Union cohesion policy. Regional Studies, vol. 49, no 8, pp. 1291-1302.

McCann P., Ortega-Argilés R. (2016) The early experience of smart specialization implementation in EU cohesion policy. European Planning Studies, vol. 24, no 8, pp. 1407-1427.

Moretti E. (2012) The new geography of jobs, Boston: Houghton Mifflin Harcourt. 
Morgan K. (1997) The learning region: Institutions, innovation and regional renewal. Regional Studies, vol. 5, no 31, pp. 491-504.

Morgan K., Nauwelaers C. (1999) Regional innovation strategies: The challenge for less favoured regions, London: Psychology Press.

Nelson P. (1997) Migration, sources of income, and community change in the nonmetropolitan Northwest. Professional Geographer, vol. 49, no 4, pp. 418-430.

NSF(2007) Expendituresfor U.S. IndustrialReDContinuetoIncrease in 2005; ReDPerformance Geographically Concentrated, Arlington, VA: National Science Foundation. Available at: https://wayback.archive-it.org/5902/20160210164445/ http://www.nsf.gov/statistics/infbrief/nsf07335/nsf07335.pdf, accessed 22.02.2017.

OECD (2011) Regions and Innovation Policy, Paris: OECD.

OECD (2012a) Promoting Growth in All Regions, Paris: OECD.

OECD (2012b) Science, Technology and Industry Outlook 2012, Paris: OECD.

OECD (2013a) Regions and Innovation: Collaborating across Borders, Paris: OECD.

OECD (2013b) Innovation-driven growth in regions: The role of smart specialisation, Paris: OECD.

OECD, Eurostat (2005) Oslo Manual: Guidelines for Collecting and Interpreting Innovation Data (3rd ed.), Paris: OECD, Eurostat.

Porter M. (1990) The Competitive Advantage of Nations, New York: Basic Books.

Porter M. (1998) Clusters and the new economics of competition. Harvard Business Review, vol. 76, no 6, pp. 77-90.

Reid A., Stanovnik P. (2013) The Development of a Smart Specialisation Strategy for Slovenia: Report to the European Commission, Brussels: EC, Directorate General Research and Innovation.

Ricardo D. (1817) On the Principles of Political Economy and Taxation (1st ed.), London: John Murray.

Rosstat (2016) Regiony Rossii. Sotsial'no-ekonomicheskie pokazateli - 2016 g. [Regions of Russia. Social and economic indicators - 2016]. Available at: http://www.gks.ru/bgd/regl/b16_14p/Main.htm, accessed 22.02.2017 (in Russian).

Smith K. (2006) Measuring Innovation. The Oxford Handbook of Innovation (eds. J. Fagerberg, D. Mowery, R. Nelson), Oxford: Oxford University Press, pp. 86-114. Available at: http://www.oxfordhandbooks.com/view/10.1093/ oxfordhb/9780199286805.001.0001/oxfordhb-9780199286805-e-6, accessed 22.02.2017.

Technopolis Group (2011) Regional Innovation Monitor. Innovation Patterns and Innovation Policy in European Regions - Trends, Challenges and Perspectives. 2010 Annual Report, Brussels: European Commission.

Thissen M., Oort F., Diodato D. (2013) Integration and convergence in regional Europe: European regional trade flows from 2000 to 2010, The Hague: PBL Netherlands Environmental Assessment Agency. Available at: http://www.pbl. $\mathrm{nl} /$ sites/default/files/cms/publicaties/PBL_2013_European\%20Regional\%20Trade\%20Flows\%20from\%2020002010_1036.pdf, accessed 22.02.2017.

Tödtling F., Trippl M. (2005) One size fits all?: Towards a differentiated regional innovation policy approach. Research Policy, vol. 34, no 8, pp. 1203-1219.

U.S. Census Bureau (2016) Population clock. Available at: http://www.census.gov/popclock/2 accessed 22.02.2017.

UNECE (2014) Report for the Seventh session of the Team of Specialists on Innovation and Competitiveness Policies, Geneva, 16-17 October 2014, Geneva: United Nations. Available at: https://www.unece.org/fileadmin/DAM/ project-monitoring/4-economic-cooperation-and-integration/ECE.CECI.ICP.2014.2_as_adopted.pdf, accessed 22.02.2017.

UNECE (2015) Smart Specialisation Strategies for Sustainable Development, Geneva: United Nations. Available at: http://www.unece.org/index.php?id=35927\#/, accessed 22.02.2017.

Vicario L., Monje P. (2003) Another "Guggenheim Effect"? The generation of a potentially gentrifiable neighbourhood in Bilbao. Urban Studies, vol. 40, no 12, pp. 2383-2400.

Warwick K. (2013) Beyond industrial policy: Emerging issues and new trends (OECD Science, Technology and Industry Policy Paper no 2). Paris: OECD. Available at: http://dx.doi.org/10.1787/5k4869clw0xp-en, accessed 19.01.2017.

World Bank (2010) Innovation Policy: A Guide for Developing Countries, Washington: World Bank Group.

Xunta de Galicia (2014) Smart Specialisation Strategy in Galicia 2014-2020, Santiago de Compostela: Econet S.L. 